\title{
Principles and utilization of combining ability in plant breeding
}

\begin{abstract}
In any hybridization program, recognition of the best combination of two (or more) parental genotypes to maximize variance within related breeding populations, and as a result the chance of recognizing superior transgressive segregants in the segregating populations, are the most critical challenge to plant breeders. Since the combining ability was introduced in 1942, it has been widely adopted in plant breeding to compare performances of lines in hybrid combinations. In addition, the ability to predict optimal genotype combinations for different traits based on molecular-based genetic data would greatly enhance the efficiency of plant breeding programmes. This article reviews our current understanding of combining ability in plant breeding as well as recent advances in research in this field. It brings an introduction to combining ability and the concept of general and specific combining ability, methods for estimating combining ability, and QTL mapping of related traits.
\end{abstract}

Keywords: combining ability, general combining ability, mating designs, quantitative trait loci, specific combining ability
Volume 4 Issue I - 2016

\author{
Parviz Fasahat,' Abazar Rajabi,' Javad \\ Mohseni Rad, ${ }^{2}$ John Derera ${ }^{3}$ \\ 'Sugar Beet Seed Institute, Education and Extension \\ Organization (AREEO), Iran \\ ${ }^{2}$ Agricultural Research, Education and Extension Organization \\ (AREEO), Iran \\ ${ }^{3}$ School of Agricultural, University of KwaZulu-Natal, South \\ Africa
}

Correspondence: Parviz Fasahat, Sugar Beet Seed Institute, Agricultural Research, Education and Extension Organization (AREEO), Karaj, Iran, Email parviz.fasahat@gmail.com

Received: May 25, 2016 | Published: June 30, 2016

Abbreviations: NC; north carolina, SE; standard errors, RRS; reciprocal recurrent selection, QPM; quality protein maize, TC; test crosses, BC; back crosses, RI; recombinant inbred, ILs; introgression lines, DH; double haploids, NIL; near isogenic line, SSIL; single segment introgression line, MAS; marker assisted selection

\section{Introduction}

Identification of the best performing lines (for commercial release) and lines which can be used as parents in future crosses are two principal objects considering in most crop breeding programs. ${ }^{1}$ The best performing lines for required characteristics are selected based on conducting multi-environment trials following statistical analysis. A well-designed trial accompanied by statistical analysis distinguishes genetic and environmental influences. The parental lines selection can be performed by particular mating designs such as line $\times$ tester, North Carolina (NC) designs I, II and III, and diallel. Through conducting such designs, the genetic influences of a line can be partitioned into additive and non-additive components. ${ }^{1,2}$

\section{Definition of combining ability}

Crossing a line to several others provides the mean performance of the line in all its crosses. Combining ability or productivity in crosses is defined as the cultivars or parents ability to combine among each other during hybridization process such that desirable genes or characters are transmitted to their progenies. In another definition, combining ability is an estimation of the value of genotypes on the basis of their offspring performance in some definite mating design. ${ }^{3}$ It can seldom be envisaged only based on parental phenotype and thus it is measured by progeny testing. When parental plants produce potent offspring, they are said to have good combining ability. ${ }^{4}$

At first, combining ability was a general concept used collectively for classifying an inbred line respective to its cross performance but was later amended. Two concepts of general combining ability
(GCA) and specific combining ability (SCA) have had important influence on inbred line evaluation and population development in crop breeding. ${ }^{5}$ Sprague and Tatum ${ }^{5}$ defined GCA as the average performance of a genotype in a series of hybrid combinations. They defined SCA as those cases in which certain hybrid combinations perform better or poorer than would be expected on the basis of the average performance of the parental inbred lines. Parents showing a high average combining ability in crosses are considered to have good GCA while if their potential to combine well is bounded to a particular cross, they are considered to have good SCA.

From a statistical point of view, the GCA is a main effect and the SCA is an interaction effect. ${ }^{6}$ Based on Sprague and Tatum, ${ }^{5}$ GCA is owing to the activity of genes which are largely additive in their effects as well as additive $\times$ additive interactions. ${ }^{7}$ Specific combining ability is regarded as an indication of loci with dominance variance (non-additive effects) and all the three types of epistatic interaction components if epistasis were present. They include additive $\times$ dominance and dominance $\times$ dominance interactions.

It is obvious from the foregoing definitions that the combining ability of lines for main characteristics is estimated by examining a set of designed progeny in good trial design accompanied by statistical analysis. Furthermore, parent selection for combining ability is conducted through growing and evaluating the progenies. ${ }^{8}$

\section{GCA and SCA}

Combining ability studies have been conducted in many crops ranging from cereals, roots to legumes, indicating that it is a crucial tool in plant breeding. As shown in Table 1, GCA effects for parents and SCA effects for crosses were estimated in different crops, such as wheat, ${ }^{9,10}$ sunflower, ${ }^{11}$ rice, ${ }^{12}$ sorghum, ${ }^{13}$ maize,,${ }^{8,14}$ cotton,,${ }^{15}$ and chickpea. ${ }^{16}$ Interesting combining ability analyses were recently performed in watermelon ${ }^{17}$ and oil palm. ${ }^{18}$ 
Table I GCA and SCA dominance for different traits

\begin{tabular}{|c|c|c|c|c|c|}
\hline Crop Species & Experimental Material & Type of Cross & GCA Dominance & SCA Dominance & References \\
\hline $\begin{array}{l}\text { Cotton (Gossypium } \\
\text { hirsutum L.) }\end{array}$ & $\begin{array}{l}7 \text { testers/restorers } \\
\text { (male parents) and three } \\
\text { cytoplasmic genetic male- } \\
\text { sterile lines (female parents) }\end{array}$ & Line $\times$ tester & $\begin{array}{l}\text { Bundle strength and fiber } \\
\text { elongation }\end{array}$ & $\begin{array}{l}\text { Seed cotton yield, gin } \\
\text { turnout, and micronaire }\end{array}$ & 19 \\
\hline Cotton & I0 F2 hybrid populations & Half diallel & $\begin{array}{l}\text { Lint yield, lint percentage, } \\
\text { boll number, lint index, boll } \\
\text { weight, seeds per boll }\end{array}$ & $\begin{array}{l}\text { Lint index, boll weight, } \\
\text { seeds per boll }\end{array}$ & 15 \\
\hline Maize (Zea mays L.) & 16 inbred lines & Factorial design & $\begin{array}{l}\text { Grain and stover yield, } \\
\text { stover fodder quality }\end{array}$ & Grain and stover yield & 20 \\
\hline Maize (Zea mays L.) & 9 elite inbred lines & Diallel & Kernel rows per ear & $\begin{array}{l}\text { Grain yield, kernels per } \\
\text { row }\end{array}$ & 14 \\
\hline Maize (Zea mays L.) & $\begin{array}{l}\text { I I fixed inbred lines and one } \\
\text { open-pollinated variety }\end{array}$ & Diallel & $\begin{array}{l}\text { Grain yield, anthesis date, } \\
\text { grain texture, plant height }\end{array}$ & $\begin{array}{l}\text { Anthesis silking interval } \\
\text { (days), ears per plant, } \\
\text { husk cover, root lodging } \\
\text { and ear position }\end{array}$ & 21 \\
\hline Maize (Zea mays L.) & I5 inbred lines & Diallel & Grain yield & - & 22 \\
\hline Maize (Zea mays L.) & 12 inbred lines & Diallel & & Grain yield & 23 \\
\hline Maize (Zea mays L.) & 8 inbred lines & Diallel & $\beta$-carotene content & & 25 \\
\hline Maize (Zea mays L.) & 10 inbred lines & Diallel & Total carotenoids & & 26 \\
\hline $\begin{array}{l}\text { Popcorn (Zea mays } \\
\text { L.) }\end{array}$ & $\begin{array}{l}9 \text { lines (eight tropical and one } \\
\text { temperate lines) }\end{array}$ & Diallel & & Seed quality & 27 \\
\hline $\begin{array}{l}\text { Artemisia annua } \\
\text { (asteraceae) }\end{array}$ & 30 parental lines & Diallel & $\begin{array}{l}\text { Artemisinin concentration } \\
\text { and biomass }\end{array}$ & & 28 \\
\hline $\begin{array}{l}\text { Cauliflower (Brassica } \\
\text { oleracea var. botrytis } \\
\text { L.) }\end{array}$ & $\begin{array}{l}5 \mathrm{CMS} \text { lines were crossed } \\
\text { with } 8 \text { male fertile lines }\end{array}$ & Line $\times$ tester & $\begin{array}{l}\text { Ascorbic acid, anthocyanins, } \\
\text { lycopene, total carotenoids, } \\
\beta \text {-carotene }\end{array}$ & $\begin{array}{l}\text { Ascorbic acid, } \\
\text { anthocyanins, lycopene, } \\
\text { total carotenoids, } \beta \\
\text {-carotene }\end{array}$ & 29 \\
\hline Sunflower & $\begin{array}{l}\text { I09 female S3 cytoplasmic } \\
\text { male sterile (CMS) lines } \\
\text { crossed with two testers }\end{array}$ & testcross & Seed yield and oil yield & Oil content & {$[30]$} \\
\hline
\end{tabular}




\begin{tabular}{|c|c|c|c|c|c|}
\hline Crop Species & Experimental Material & Type of Cross & GCA Dominance & SCA Dominance & References \\
\hline Sunflower & $\begin{array}{l}7 \text { male sterile lines with four } \\
\text { restorers }\end{array}$ & Line $\times$ tester & $\begin{array}{l}\text { Seed weight per head, head } \\
\text { diameter and hull content }\end{array}$ & Oil content & 31 \\
\hline Sunflower & $\begin{array}{l}20 \text { cytoplasmic male sterile } \\
\text { inbred lines and four testers }\end{array}$ & Factorial design & $\begin{array}{l}\text { Oil content, plant height } \\
\text { and } 1000 \text {-kernel weight }\end{array}$ & Seed yield & 32 \\
\hline $\begin{array}{l}\text { Cowpea (Vigna } \\
\text { unguiculata (L.) } \\
\text { Walp) }\end{array}$ & 7 cultivars & Half diallel & $\begin{array}{l}\text { Days to flowering, grain } \\
\text { filling period, days to } \\
\text { maturity, pod length, } \\
\text { number of seeds per pod, } \\
\text { number of nodules, I00- } \\
\text { seed weight, grain yield }\end{array}$ & $\begin{array}{l}\text { Days to flowering, grain } \\
\text { filling period, days to } \\
\text { maturity, pod length, } \\
\text { number of pods per plant, } \\
\text { number of seeds per pod, } \\
\text { l00- seed weight }\end{array}$ & 33 \\
\hline $\begin{array}{l}\text { Alfalfa (M. sativa ssp. } \\
\text { sativa L.) }\end{array}$ & 5 cultivars & Diallel & $\begin{array}{l}\text { Green forage yield, plant } \\
\text { height, number of stems, } \\
\text { regrowth rate }\end{array}$ & $\begin{array}{l}\text { Green forage yield, plant } \\
\text { height, number of stems, } \\
\text { regrowth rate }\end{array}$ & 34 \\
\hline $\begin{array}{l}\text { Alfalfa (Medicago } \\
\text { sativa L.) }\end{array}$ & 9 germplasms & Diallel & Forage yield & Forage yield & 35 \\
\hline $\begin{array}{l}\text { Alfalfa (Medicago } \\
\text { sativa L.) }\end{array}$ & 9 germplasms & Diallel & Forage yield & Forage yield & 36 \\
\hline $\begin{array}{l}\text { Alfalfa (Medicago } \\
\text { sativa L.) }\end{array}$ & 9 germplasms & Diallel & Forage yield & Forage yield & 37 \\
\hline Rice (Oryza sativa L.) & $\begin{array}{l}\text { hybridization of } 30 \text { elite indica } \\
\text { TGMS lines and } 4 \text { cultivars, } \\
\text { viz., Pant Dhan } 4 \text { and Ajaya } \\
\text { (indica), Taichung } 65 \text { (japonica) } \\
\text { and IR } 65598-\text { I I 2-2 (tropical } \\
\text { japonica) }\end{array}$ & Line $\times$ tester & $\begin{array}{l}\text { Grain yield per plant, days } \\
\text { to } 50 \% \text { flowering, panicle } \\
\text { number per plant, panicle } \\
\text { length, grain number per } \\
\text { panicle, } 1000 \text { grain weight }\end{array}$ & $\begin{array}{l}\text { Grain yield per plant, days } \\
\text { to } 50 \% \text { flowering, panicle } \\
\text { number per plant, panicle } \\
\text { length, grain number per } \\
\text { panicle }\end{array}$ & 38 \\
\hline Rice (Oryza sativa L.) & $\begin{array}{l}3 \text { photo-thermo-sensitive } \\
\text { genie male sterile (PTGMS) } \\
\text { lines with a BCRIL population }\end{array}$ & $\mathrm{NCll}$ & $\begin{array}{l}\text { Plant height, tillers per } \\
\text { plant, panicle length, full } \\
\text { grains per plant, seed } \\
\text { setting rate, grains per } \\
\text { panicle, spikelets per } \\
\text { panicle, grain density }\end{array}$ & $\begin{array}{l}\text { Plant height, tillers per } \\
\text { plant, panicle length, full } \\
\text { grains per plant, seed } \\
\text { setting rate, grains per } \\
\text { panicle, spikelets per } \\
\text { panicle, grain density }\end{array}$ & 39 \\
\hline Rice & $\begin{array}{l}7 \text { diverse genotypes (including } \\
\text { a few traditional cultivars and } \\
\text { land races) }\end{array}$ & Half diallel & $\begin{array}{l}\text { Days to } 50 \% \text { flowering, } \\
\text { grain filling period, plant } \\
\text { height, panicle length, flag } \\
\text { leaf area, } 100 \text { grain weight, } \\
\text { harvest index, grain yield }\end{array}$ & $\begin{array}{l}\text { Days to } 50 \% \text { flowering, } \\
\text { grain filling period, plant } \\
\text { height, panicle length, } \\
\text { flag leaf area, } 100 \text { grain } \\
\text { weight, harvest index, } \\
\text { grain yield, number of } \\
\text { productive tiller, number } \\
\text { of spikelets per panicle }\end{array}$ & 30 \\
\hline $\begin{array}{l}\text { hexaploid wheat } \\
\text { (Triticum aestivum L. } \\
\text { em.Thell) }\end{array}$ & $\begin{array}{l}10 \text { varieties of hexaploid } \\
\text { wheat }\end{array}$ & Diallel & $\begin{array}{l}\text { Days to heading, days to } \\
\text { maturity, plant height, flag } \\
\text { leaf area, tiller per plant, } \\
\text { spike length, grain yield per } \\
\text { spike, } 1000 \text { grain weight, } \\
\text { harvest index, grain yield } \\
\text { per plant, protein content }\end{array}$ & $\begin{array}{l}\text { Days to heading, days to } \\
\text { maturity, plant height, flag } \\
\text { leaf area, tiller per plant, } \\
\text { spike length, grain yield } \\
\text { per spike, I000 grain } \\
\text { weight, harvest index, } \\
\text { grain yield per plant, } \\
\text { protein content }\end{array}$ & 27 \\
\hline
\end{tabular}


Table Continued

\begin{tabular}{|c|c|c|c|c|c|}
\hline Crop Species & Experimental Material & Type of Cross & GCA Dominance & SCA Dominance & References \\
\hline $\begin{array}{l}\text { Spring wheat } \\
\text { (Triticum aestivum L. } \\
\text { em.Thell) }\end{array}$ & 5 cultivars & Diallel & $\begin{array}{l}\text { Spike length, spikelets per } \\
\text { spike, grains per spike, grain } \\
\text { yield per spike, grain length, } \\
\text { grain width, grain area, grain } \\
\text { sphericity }\end{array}$ & $\begin{array}{l}\text { Spike length, spikelets } \\
\text { per spike, grain yield per } \\
\text { spike, grain weight, grain } \\
\text { length, grain width, grain } \\
\text { area }\end{array}$ & 94 \\
\hline $\begin{array}{l}\text { Wheat (Triticum } \\
\text { aestivum L.) }\end{array}$ & 7 parents & Diallel & $\begin{array}{l}\text { Spike length, flag leaf area, } \\
\text { number of spikes per plant, } \\
\text { number of spikelets per } \\
\text { spike, kernels per spike, } \\
1000 \text { kernel weight, grain } \\
\text { yield per plant }\end{array}$ & $\begin{array}{l}\text { Spike length, flag leaf area, } \\
\text { number of spikes per } \\
\text { plant, number of spikelets } \\
\text { per spike, kernels per } \\
\text { spike, I } 1000 \text { kernel weight, } \\
\text { grain yield per plant }\end{array}$ & 9 \\
\hline $\begin{array}{l}\text { Bread wheat } \\
\text { (Triticum aestivum L.) }\end{array}$ & 5 cultivars & Half diallel & $\begin{array}{l}\text { Embryogenic callus, plant } \\
\text { regeneration, heading date, } \\
\text { grain yield per plant }\end{array}$ & $\begin{array}{l}\text { Embryogenic callus, plant } \\
\text { regeneration, heading } \\
\text { date, grain yield per plant }\end{array}$ & 10 \\
\hline $\begin{array}{l}\text { Durum wheat } \\
\text { (Triticum durum } \\
\text { Desf.) }\end{array}$ & $\begin{array}{l}3 \text { local populations and one } \\
\text { cultivar of durum wheat }\end{array}$ & Diallel & $\begin{array}{l}\text { Kernel length, kernel } \\
\text { width, kernel height, kernel } \\
\text { projected area, kernel } \\
\text { sphericity, kernel rupture } \\
\text { strength, I } 000 \text { kernel } \\
\text { weight }\end{array}$ & $\begin{array}{l}\text { Kernel length, kernel } \\
\text { width, kernel height, } \\
\text { kernel projected area, } \\
\text { kernel sphericity, kernel } \\
\text { rupture strength, } 1000 \\
\text { kernel weight }\end{array}$ & 2 \\
\hline $\begin{array}{l}\text { Sorghum [Sorghum } \\
\text { bicolor (L.) Moench]. }\end{array}$ & 15 parents & Diallel & $\begin{array}{l}\text { Fe and } \mathrm{Zn} \text { concentration, } \\
\text { grain yield }\end{array}$ & $\begin{array}{l}\text { Fe and } \mathrm{Zn} \text { concentration, } \\
\text { grain yield }\end{array}$ & 43 \\
\hline $\begin{array}{l}\text { Sorghum [Sorghum } \\
\text { bicolor (L.) Moench]. }\end{array}$ & $\begin{array}{l}15 \text { restorers and } 5 \text { male- } \\
\text { sterile } \mathrm{A} \text {-lines }\end{array}$ & Line $\times$ tester & $\begin{array}{l}\text { Grain yield, days to anthesis, } \\
\text { plant height, inflorescence } \\
\text { length, threshing } \\
\text { percentage, and seed mass }\end{array}$ & $\begin{array}{l}\text { Grain yield, days to } \\
\text { anthesis, plant height, } \\
\text { threshing percentage, and } \\
\text { seed mass }\end{array}$ & 44 \\
\hline Sorghum & $\begin{array}{l}8 \text { cytoplasmic male-sterile } \\
\text { (CMS) A-lines were } \\
\text { designated as females and } \\
\text { crossed to } 10 \text { cytoplasmic } \\
\text { male-fertile lines }\end{array}$ & $\mathrm{NCll}$ & $\begin{array}{l}\text { Grain yield, weight of } 1000 \\
\text { seeds, head length, number } \\
\text { of leaves plant-I, number } \\
\text { of tillers plant-I, days to } \\
50 \% \text { flowering, days to } 95 \% \\
\text { maturity }\end{array}$ & $\begin{array}{l}\text { Grain yield, weight of } \\
1000 \text { seeds, head length, } \\
\text { number of leaves plant-I, } \\
\text { number of tillers plant-I, } \\
\text { days to } 50 \% \text { flowering, } \\
\text { days to } 95 \% \text { maturity }\end{array}$ & 13 \\
\hline $\begin{array}{l}\text { Sweet Sorghum } \\
\text { (Sorghum bicolor (L.) } \\
\text { Moench.) }\end{array}$ & 8 parents and 16 hybrids & Line $\times$ tester & & $\begin{array}{l}\text { Juice extraction, grain } \\
\text { yield }\end{array}$ & 45 \\
\hline Rye & 5 inbred lines & Diallel & $\begin{array}{l}\text { Grain test weight, falling } \\
\text { number, protein content, } \\
\text { water extract viscosity, } \\
\text { hearth bread form ratio, } \\
\text { and pan loaf volume }\end{array}$ & $\begin{array}{l}\text { Grain test weight, falling } \\
\text { number, protein content, } \\
\text { water extract viscosity, } \\
\text { hearth bread form ratio, } \\
\text { and pan loaf volume }\end{array}$ & 46 \\
\hline Chickpea & 4 genotypes & Diallel & $\begin{array}{l}\text { Days to flowering, plant } \\
\text { height, number of pods, } \\
\text { seeds per plant }\end{array}$ & $\begin{array}{l}\text { Days to maturity, basal } \\
\text { pod height, number of } \\
\text { branches per plant and } \\
\text { l00-seed weight }\end{array}$ & 16 \\
\hline $\begin{array}{l}\text { Hot pepper } \\
\text { (Capsicum annuum } \\
\text { L.) }\end{array}$ & 12 inbred lines & Half diallel & $\begin{array}{l}\text { Days to flowering, early } \\
\text { yield, number of fruits } \\
\text { plant, fruit length, fruit } \\
\text { width, average fruit weight, } \\
\text { pericarp thickness, number } \\
\text { of seeds fruit, plant height, } \\
\text { plant spread, total fruit yield }\end{array}$ & $\begin{array}{l}\text { Days to flowering, early } \\
\text { yield, number of fruits } \\
\text { plant, fruit length, fruit } \\
\text { width, average fruit } \\
\text { weight, pericarp thickness, } \\
\text { number of seeds fruit, } \\
\text { plant height, plant spread, } \\
\text { total fruit yield }\end{array}$ & 47 \\
\hline
\end{tabular}


Table Continued

\begin{tabular}{|c|c|c|c|c|c|}
\hline Crop Species & Experimental Material & Type of Cross & GCA Dominance & SCA Dominance & References \\
\hline $\begin{array}{l}\text { Safflower (Carthamus } \\
\text { tinctorius L.) }\end{array}$ & 8 genotypes & Diallel & $\begin{array}{l}\text { Linoleic, oleic, palmitic, and } \\
\text { stearic acids, oil content, } \\
\text { protein content }\end{array}$ & $\begin{array}{l}\text { Linoleic, oleic, palmitic, } \\
\text { and stearic acids, oil } \\
\text { content, protein content }\end{array}$ & 48 \\
\hline $\begin{array}{l}\text { Sesame (Sesamum } \\
\text { indicum L.) }\end{array}$ & 7 genotypes & Half diallel & $\begin{array}{l}\text { Crop growth rate, leaf } \\
\text { rate index, days to peak } \\
\text { flowering, duration of } \\
\text { flowering, duration from } \\
\text { peak flowering to maturity, } \\
\text { oil content, oil yield per } \\
\text { plant }\end{array}$ & $\begin{array}{l}\text { Crop growth rate, leaf } \\
\text { rate index, days to peak } \\
\text { flowering, duration of } \\
\text { flowering, duration } \\
\text { from peak flowering to } \\
\text { maturity, oil content, oil } \\
\text { yield per plant }\end{array}$ & 49 \\
\hline $\begin{array}{l}\text { Tomato (Solanum } \\
\text { lycopersicum L.) }\end{array}$ & 5 cultivars & Diallel & $\begin{array}{l}\text { Plant height, number of } \\
\text { primary branches, fruit } \\
\text { shape index, number of } \\
\text { locules per fruit, pericarp } \\
\text { thickness, number of fruits } \\
\text { per plant, fruit weight, total } \\
\text { soluble solids, fruit firmness, } \\
\text { ascorbic acid content }\end{array}$ & $\begin{array}{l}\text { Plant height, number of } \\
\text { primary branches, fruit } \\
\text { shape index, number of } \\
\text { locules per fruit, pericarp } \\
\text { thickness, number of } \\
\text { fruits per plant, fruit } \\
\text { weight, number of } \\
\text { flowers per cluster, total } \\
\text { soluble solids }\end{array}$ & 50 \\
\hline $\begin{array}{l}\text { Basil (Ocimum } \\
\text { basilicum L.) }\end{array}$ & 4 cultivars & Diallel & $\begin{array}{l}\text { Plant height, canopy } \\
\text { diameter, leaf length, } \\
\text { leaf width, leaf dry mass, } \\
\text { essential oil yield, essential } \\
\text { oil content }\end{array}$ & $\begin{array}{l}\text { Plant height, canopy } \\
\text { diameter, leaf dry mass, } \\
\text { essential oil yield, } \\
\text { essential oil content }\end{array}$ & 51 \\
\hline $\begin{array}{l}\text { Linseed (Linum } \\
\text { usitatissimum L.) }\end{array}$ & $\begin{array}{l}19 \text { diverse genotypes ( } 14 \text { lines } \\
\text { and five diverse testers) }\end{array}$ & Line $\times$ tester & $\begin{array}{l}\text { Days to } 50 \% \text { flowering, } \\
\text { days to maturity, plant } \\
\text { height, primary branches, } \\
\text { secondary branches, seed } \\
\text { weight, seed yield, harvest } \\
\text { index, oil content }\end{array}$ & $\begin{array}{l}\text { Days to } 50 \% \text { flowering, } \\
\text { days to maturity, plant } \\
\text { height, primary branches, } \\
\text { secondary branches, seed } \\
\text { weight, seed yield, harvest } \\
\text { index, oil content }\end{array}$ & 52 \\
\hline
\end{tabular}

Importance of combining ability in applied genetics including plant and animal breeding cannot be overemphasized. The GCA concept has been effectively used in crop and livestock breeding for more than 70 years. ${ }^{5,53-55}$ GCA is an effective tool used in selection of parents based on performance of their progenies, usually the $F_{1}$ but it has also been used in $\mathrm{F}_{2}$ and later generations $\left(\mathrm{F}_{\mathrm{n}}\right)$. A low GCA value, positive or negative, shows that the mean of a parent in crossing with the other does not vary largely from the general mean of the crosses. In contrast, a high GCA value shows that the parental mean is superior or inferior to the general mean. This indicates a potent evidence of desirable gene flow from parents to offspring at high intensity and represents information regarding the concentration of predominantly additive genes. ${ }^{56} \mathrm{~A}$ high GCA estimate indicates higher heritability and less environmental effects. It may also result in less gene interactions and higher achievement in selection. ${ }^{2,30}$ One of the main features of the elite parent with high GCA effect is its large adaptability. A parent good in per se performance may not necessarily produce better hybrids when used in hybridization. ${ }^{3,38,57}$ Concurrently, it also indicated that one parent of the worst combination could make the best combination if the other parent was selected properly. ${ }^{9}$

In GCA determination, SCA usually acts as a masking effect. By using genetically broad testers or increasing number of testers, SCA impact can be decreased. ${ }^{58}$ Parental choice only on the basis of SCA effect has limited value in breeding programs. Therefore, SCA effect should be used in combination with a high performance per se hybrid, favourable SCA estimates, and involving at least one parent with high GCA. ${ }^{13,41,44,56}$

Observations of performance of different cross patterns on the basis of SCA have been used to make inferences on gene action at play. High SCA effects resulting from crosses where both parents are good general combiners (i.e., good GCA $\times$ good GCA) may be ascribed to additive $\times$ additive gene action. ${ }^{29,40}$ The high SCA effects derived from crosses including good $\times$ poor general combiner parents $s^{29,34,40}$ may be attributed to favourable additive effects of the good general combiner parent and epistatic effects of poor general combiner, which fulfils the favourable plant attribute. High SCA effects manifested by low $\times$ low crosses $^{29,30}$ may be due to dominance $\times$ dominance type of non-allelic gene interaction producing over dominance thus being non-fixable. ${ }^{59}$ Predominance of non-additive effects has been reported for inheritance of pod yield and related traits in groundnut under salinity stress in which there were cross combinations with high SCA effects arising from parents with high and low GCA, and another set of crosses with high SCA effects arising from both parents with good GCA effects. ${ }^{60}$ 


\section{Relative importance of combining ability}

Different methods have been used to evaluate relative importance of GCA and SCA in plant breeding. The first step is to check whether or not both GCA and SCA are significant at $\mathrm{P}=0.05$ or at higher probability levels $(0.01$ or 0.001 etc.). If both the GCA and SCA values are not significant, epistatic gene effects may play a remarkable role in determining these characters. ${ }^{61}$

The ratio of combining ability variance components (predictability ratio) determines the type of gene action involved in the expression of traits and allows inferences about optimum allocation of resources in hybrid breeding:

$$
\frac{2 \sigma^{2} \text { gca }}{2 \sigma^{2} \text { gca }+\sigma^{2} \text { sca }}
$$

in which $\sigma^{2}$ gca refers to general combining ability variance and $\sigma^{2}$ sca refers to specific combining ability variance. The closer this ratio is to one, the greater the prediction of GCA alone, whereas a ratio with a value less than 1 shows SCA action. ${ }^{62,63}$ However, because in many cases only a few parents are used in crosses, the magnitude of GCA and SCA has been evaluated using the ratio of their sum of squares to total sum of squares for crosses. ${ }^{64}$

\section{Early testing}

Relative contributions of GCA and SCA to crosses can be used to make important decisions in plant breeding. When GCA variances prevail over SCA variances, early generation examining of genotypes becomes more efficient and promising hybrids can be recognized and selected based on their prediction from GCA effects. ${ }^{65,66}$ The GCA performance of relatively later lines can be predicted by using a GCA of a line in an early generation ${ }^{8}$ and the scientific reason for this observation is that the GCA is controlled by genetic material, is heritable and can be transmitted to the offspring. ${ }^{8}$ This makes hybrid cultivar improvement more effective and less costly via less time taken to release hybrids and fewer materials carried in breeding programs. While in the presence of non-additive component, selection should be undertaken in later generations when these impacts are fixed in the homozygous lines. ${ }^{9,16,20,22,30,67}$

\section{Techniques for estimation of combining ability}

With a progress in biometrical genetics, several techniques are suggested for the estimation of combining ability. These include top cross suggested by Davis ${ }^{68}$ and developed by Jenkins and Brunaon, ${ }^{69}$ poly cross technique proposed by Tysdal et al., ${ }^{70}$ diallel cross analysis by Griffing, ${ }^{71}$ line $\times$ tester analysis by Kempthorne, ${ }^{72}$ partial diallel cross by Kempthorne \& Curnow, ${ }^{73}$ North Carolina design by Comstock \& Robinson ${ }^{74}$ and triallel cross by Rawlings \& Cockerham $^{75}$ are used to estimate combining ability. Since a detailed discussion of these methods could form the basis of a separate review, the present account will be limited to the three main methods namely diallel, line $\times$ tester and North Carolina designs, which are mostly used in different studies.

\section{Diallel design}

In diallel mating, the parental lines cross in all possible combinations (both direct as well as reciprocal crosses) to recognize parents as best or poor general combiners by GCA and the specific cross combinations by SCA. Complete diallel cross designs entail the occurrences of equal numbers of each of the different crosses among $p$ inbred lines. When $p$, is large, or reciprocal crosses are analogous to direct crosses it becomes impractical to conduct an experiment using a complete diallel cross design. In such circumstances, partial diallel cross designs (a subset of crosses) can be used.

The most frequently used methods in the diallel analysis are Griffing's ${ }^{71}$ diallel procedures. Griffing ${ }^{71}$ suggested four different diallel methods for use in plants: 1) Method 1 (full diallel): parents, $\mathrm{F}_{1}$ and reciprocals, 2) Method 2 (half diallel): parents and $\mathrm{F}_{1}$ 's, 3) Method 3: $F_{1}$ 's and reciprocals, 4) Method 4: $F_{1}$ 's. These four methods have been widely used to study the patterns of inheritance of different traits in many crops..$^{27,28,76,77}$ These diallel methods of Griffing ${ }^{71}$ are generally used for one year or one location trials however, multienvironment trials are suggested to produce more reliable genetic information on material tested. ${ }^{78}$ Moreover, it has been illustrated that the early information on the genetic behaviour of these traits can be obtained by diallel cross method., 2,79

All the diallel types estimate variation due to the crosses (Table 2) which is partitioned into sources due to GCA and SCA. So the differences between the diallels are based on whether parents or reciprocal effects are included in the model. The reciprocal crosses estimate the variation due to maternal effects, which are expected for some traits. A relatively larger GCA/SCA variance ratio demonstrates importance of additive genetic effects and a lower ratio indicates predominance of dominance and/or epistatic gene effects. ${ }^{80}$ GCA and SCA effects for individual lines are calculated only when the overall analysis shows that mean squares for GCA and SCA are significant. ${ }^{81}$

\section{Line $\times$ tester design}

The line $\times$ tester is the most widely used mating design for hybrid development. Line $\times$ tester analysis which involves ' $l$ ' lines and ' $t$ ' testers is an extension of the analysis of two factor factorial experiment introduced by Fisher ${ }^{83}$ and Yates ${ }^{84}$ In this design, full-sib progenies are generated through crossing ' $l$ ' lines to ' $t$ ' testers. Then, developed progenies as well as parents, are evaluated in developed field trials. ${ }^{57,74,82}$ The combining ability in line $\times$ tester design is estimated using a formula suggested by Singh \& Chaudhary ${ }^{82}$ (see $85)$.

(c) Standard errors (SE) for combining ability effects:

$\mathrm{SE}$ of GCA for lines $=(\mathrm{MSE} / \mathrm{r} \times \mathrm{t})^{1 / 2}$; SE of GCA for testers $=$ $(\mathrm{MSE} / \mathrm{r} \times 1)^{1 / 2} ; \mathrm{SE}$ of SCA effects $=(\mathrm{MSE} / \mathrm{r})^{1 / 2}$;

where $\mathrm{MSE}=$ mean square error from the analysis of variance table.

A tester is a genotype that is used to identify superior germplasm in accordance with breeding objectives in a hybrid-oriented program. A tester line as defined by different researchers ${ }^{86-88}$ is the one that have simplicity in use, provide information that classifies relative performance of lines into heterotic groups or heterotic patterns, and maximize the expected mean yield. Heterotic patterns are populations or lines with high mean heterosis as a result of high genetic divergence, different in allele frequency and have high combining ability. Seemingly in coining a definition for a tester, researchers have been influenced by their quest to find the best or most convenient tester for use in hybrid programs. Smith ${ }^{89}$ and Hallauer \& Miranda ${ }^{58}$ assert that a line or a population with low frequency of favourable alleles in testcrosses can be employed as a tester to find lines with large frequency of favourable alleles. Such testers would be crucial when dominance gene action for the traits of interest is envisaged. Castellanos \& Cordova $^{90}$ point that a suitable tester is one which 
combines the following attributes: reveals large variation between testcrosses, has positive combining ability, has high and significant correlation with average of the testers used, and has acceptable per se performance. This definition is partly consistent with Russell ${ }^{91}$ who asserted that an ideal tester shows large genetic differences between testcrosses. In this regard, Hallauer \& Miranda ${ }^{58}$ have added that a line with homozygous recessive alleles would make a suitable tester for a hybrid program. The desire to find a convenient tester is reflected in Matzinger ${ }^{86}$ that a suitable tester would be easy to use and provide maximum information about the lines in other combinations and other test environments. This criterion has been used in different studies including Pswarayi \& Vivek ${ }^{21}$ and Akinwale et al., ${ }^{92}$

The materials which can be considered as testers consist of inbred lines, single cross hybrids and heterogeneous materials, which encompass open pollinated varieties, synthetic or populations. These materials fall into two broad groups namely broad genetic base (heterogeneous materials) as well as narrow genetic base testers (single crosses and inbred lines). A broad genetic based tester is considered for GCA selection while a narrow genetic based tester is used for SCA selection. Matzinger ${ }^{86}$ reported that a genetically broadbased tester contributes less to line $\times$ tester interaction than a tester with a narrow genetic base.

Testers can be selected according to the program goals and the types of hybrids developed. The initial tester is usually chosen based on experience with most commercial hybrid improvement programs using inbred parents with proven hybrid performance. The choice is made through using information on the pedigree of the genotypes being tested along with the knowledge of the performance of the tester. No single tester fulfils all these needs for all circumstances as the value of a tester is specified to a considerable proportion by the use to be made of a special group of lines. In a reciprocal recurrent selection (RRS), a suitable tester is selected from a population of the opposite heterotic group. If the objective is to evaluate lines of unknown origin at least two testers from established heterotic groups are employed as suitable testers to determine heterotic orientation of new lines. At least two elite lines from opposite heterotic groups or showing high levels of heterosis between them can be used as testers when the objective is to divide a broad-based population into two heterotic groups.

In a single-cross hybrid oriented program two lines which are employed as testers constitute the current best hybrid in the program. In the national program in Zimbabwe, for example, maize inbred lines SC and N3 which constitute the world-class maize hybrid SR52 are used as the principal testers. SR52 is an outstanding heterotic pattern (i.e., N3 x SC) and the first single cross hybrid to be commercialised in the world. ${ }^{93} \mathrm{~A}$ heterotic pattern is analogous to fitting shapes as illustrated in Figure 1 for N3 and SC. Only new lines with matching shapes would combine with either N3 or SC.

In programs that focus on three-way cross hybrids of different origins, a suitable tester would be a single cross hybrid with outstanding combining ability. For example combinations of maize inbred lines CML444 and CML395, and CML442 and CML312 are used as B and A single cross testers of this type at CIMMYT in eastern and southern Africa. However the tester can be a single cross of sister lines of the same heterotic group but with high yield potential.

Table 2a Estimates of combining ability effects for diallel methods I and II with reciprocal crosses. ${ }^{81,82}$

\begin{tabular}{|c|c|c|c|c|c|c|}
\hline Component & Method I & & & Method III & & \\
\hline & df & $\begin{array}{l}\text { Genetic Effects } \\
\text { Formula }\end{array}$ & SE & df & Genetic Effects Formula & SE \\
\hline GCA effects & $p-1$ & $\begin{array}{l}\text { GCAi = I/2p (Yi. }+ \text { Y.i }) \\
-I / p 2 Y . .\end{array}$ & $\begin{array}{l}{[(p-1 / 2 p 2)} \\
\mathrm{mse}] \mathrm{I} / 2\end{array}$ & $\mathrm{p}-\mathrm{I}$ & $g i=1 / 2 p(p-2)[p(Y i .+Y . i)-2 Y .]$. & {$[(p-I) m s e / 2 p(p-2] I / 2$} \\
\hline SCA effects & $p(p-I) / 2$ & $\begin{array}{l}\text { SCAij = I/2(Yij+Yji) - } \\
\text { I/2p(Yi.+Y.i+Yj.Yij)+I/ } \\
\text { p2Y.. }\end{array}$ & $\begin{array}{l}{[1 / 2 p 2(p 2-2 p+2)} \\
\mathrm{mse}] \mid / 2\end{array}$ & $\mathrm{p}(\mathrm{p}-3) / 2$ & $\begin{array}{l}S i j=I / 2(Y i j+Y j i)-Y i .+Y . \\
i+Y j .+Y . j)+I /(p-I)(p-2) Y . .\end{array}$ & {$[(p-3) m s e / 2(p-I)] l / 2$} \\
\hline $\begin{array}{l}\text { Reciprocal } \\
\text { effects }\end{array}$ & $p(p-I) / 2$ & $r i j=1 / 2(Y i j-Y j i)$ & {$[\mathrm{Mse} / 2] \mathrm{I} / 2$} & $\mathrm{p}(\mathrm{p}-\mathrm{I}) / 2$ & $r i j=I / 2(Y i j-Y j i)$ & {$[\mathrm{mse} / 2] \mathrm{I} / 2$} \\
\hline
\end{tabular}

$\mathrm{P}=$ number of parents.

Table 2b Estimates of combining ability effects for diallel methods II and IV without reciprocal crosses ${ }^{81,82}$

\begin{tabular}{|c|c|c|c|c|c|c|}
\hline \multirow[t]{2}{*}{ Component } & \multicolumn{3}{|l|}{ Method II } & \multicolumn{3}{|c|}{ Method IV } \\
\hline & df & $\begin{array}{l}\text { Genetic Effects } \\
\text { Formula }\end{array}$ & SE & df & Genetic Effects Formula & SE \\
\hline GCA effects & $p-1$ & $g i=1 / p+2\left[\sum(Y i .+Y i i)-2 / p Y .\right.$. & {$[(p-I) m s e / p(p+2)] I / 2$} & $\mathrm{p}-\mathrm{I}$ & $g i=1 / p(p-2)[p Y i .-2 Y .]$. & $\begin{array}{l}{[(p-I) m s e /} \\
P(p-2)] I / 2\end{array}$ \\
\hline SCA effects & $P(p-I) / 2$ & $\begin{array}{l}\text { Sij }=Y i j-I / p+2(Y i .-Y i i+Y . \\
j+Y j j+(2 /(p+I)(p+2)) Y . .\end{array}$ & $\begin{array}{l}{[2(p-l) m s e /(p+l)} \\
(p+2)] l / 2\end{array}$ & $P(p-3) / 2$ & $\begin{array}{l}\text { Sij=Yij-I/p-2(Yi. +Y.j) }+(2 /(p-I) \\
(p-2)) Y . .\end{array}$ & $\begin{array}{l}{[(p-3) \mathrm{mse} /(\mathrm{p}-} \\
\mathrm{I})] \mathrm{I} / 2\end{array}$ \\
\hline
\end{tabular}

$\mathrm{p}=$ number of parents. 
Table 3 Main heterotic groups of maize inbred lines used in Southern Africa

\begin{tabular}{|c|c|c|c|}
\hline Heterotic Group & Population of Derivation & Examples of Public Lines & Reference \\
\hline SC & Southern Cross & SC5522 & 94 \\
\hline N3 & Salisbury White & N3-2-3-3 & 94 \\
\hline K & $\mathrm{K} 64 \mathrm{R} / \mathrm{MI} 62 \mathrm{~W}$ & K64R, MI62W & 94 \\
\hline$P$ & $\begin{array}{l}\text { Natal Potchefstroom Pearl Elite Selection } \\
\text { (NPP ES) }\end{array}$ & NAW5867 & 95,96 \\
\hline I & NYHT/TY & RII8W,II37TN & 95 \\
\hline M & 2IA2.Jellicorse & M37W & 95 \\
\hline $\mathrm{F}$ & F2934T/Teko Yellow & F2834T & 95 \\
\hline CIMMYT- A & Tuxpeno, Kitale, BSSS, N3 (More Dent Type) & CML442, CML3I2 & 97 \\
\hline CIMMYT- B & $\begin{array}{l}\text { ETO, Ecuador 573, Lancaster, SC (More Flint } \\
\text { Type) }\end{array}$ & CML444, CML395 & 97 \\
\hline
\end{tabular}
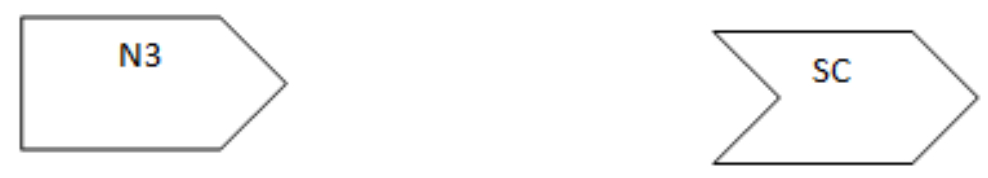

\section{SR52}

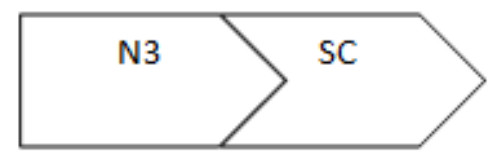

Figure I A heterotic pattern of the maize inbred lines N3 and SC.

\section{North carolina design}

The North Carolina designs can just be defined as a class of factorial mating designs or schemes where certain groups of parents are designated male (factor 1) and others female (factor 2) for use in crosses. They are useful for studying combining ability in fixed model experiments and gene action when random models are applied. Comstock \& Robinson ${ }^{98}$ proposed three types of North Carolina designs ${ }^{99}$ which are a form of bi-parental mating design. The larger the size or number of lines, the greater is the accuracy of genetic estimates achieved from the data in North Carolina designs.

In the first North Carolina design I (NC I, a polyandrous mating design), one male is crossed with a different subset of female parents, thus females are nested within males. It is a low cost controlled mating design which is generally used in animal and tree breeding. ${ }^{99}$ However a large number of sets should be used for greater accuracy achievement which decreases its effectiveness for selection goals. This design can be used to produce a large number crosses that may be required for evaluation in breeding programs.
In the North Carolina design II (NC II, also a polyandrous mating design) each member of a group of male is mated to each member of a group of females (different sets of males and females are used). In contrast to NC I, the NC II is a high cost design which contributes in restricted selection intensity. Hallauer ${ }^{100}$ suggested the NC II as a preferable design which can make use of a larger number of parents resulting in a fewer crosses generation than a diallel mating design. This design has been applied in plant breeding for selection of testcross performance. ${ }^{12,13,101}$ North Carolina II design is similar to the line $\times$ tester design. As with the line $\times$ tester design, the NC II mating design is a factorial experiment that measures the variance of male and female main effects and male $\times$ female interaction effects. ${ }^{98}$ According to Hallauer \& Miranda,${ }^{58}$ male and female main effects, and the male $\times$ female interaction effects in a NC II mating design are equivalent to the GCA and the SCA effects in a diallel. The main difference between a diallel and $\mathrm{NC}$ II is that there are two independent estimates for the GCA effects in the NC II, which is an advantage of the NC II over the diallel. Two independent estimates of GCA allow determination of maternal effects and calculation of heritability 
based on male variance, which is free from maternal effects. Another advantage is that the NC II can handle more parents and produce fewer crosses than the diallel. This is achieved by dividing parents into sets as described by Hallauer and Miranda ${ }^{58}$ and has been used in combining ability studies. ${ }^{101-103}$ In NC II, dominance variance can be determined directly from male variance. An additional advantage of the NC II is that crossing of parents in sets can increase the sample size to be tested..$^{58}$

The third North Carolina design (NC III) is to cross the $i^{\text {th }}$ individual of an $\mathrm{F}_{2}$ population to both parental lines. This design is stronger than NC I or II and the inbred parents are applied as testers to their $\mathrm{F}_{2}$ progeny. ${ }^{99}$ This design estimates dominance and additive variances and estimates dominance levels. ${ }^{98}$ It can also be used to estimate effects of linkage on additive and dominance variances. The NC III has an advantage over the NC II because it can measure levels of dominance. However, a survey of the literature indicates limited application of NC III in plant breeding. The advantages and disadvantages of the aforementioned designs are presented in Table 4.

Table 4 Advantages and disadvantages of most commonly-used combining ability methods

\begin{tabular}{|c|c|c|c|c|}
\hline Method & & Advantages & Disadvantages & References \\
\hline Diallel & & $\begin{array}{l}\text {-Estimating the combing ability of parents, gene } \\
\text { effects, and heterotic effects }\end{array}$ & $\begin{array}{l}\text {-Large amount of seed, space, time, and } \\
\text { labour required } \\
\text {-Complexity in data analysis }\end{array}$ & $104-106$ \\
\hline Line $\times$ tester & & $\begin{array}{l}\text {-Estimating the combing ability } \\
\text { of parents and gene effects } \\
\text {-Simplicity } \\
\text {-Provides both full- and half sibs }\end{array}$ & & $30,85,107,108$ \\
\hline \multirow{3}{*}{$\begin{array}{l}\text { North Carolina } \\
\text { (NC) designs }\end{array}$} & $\mathrm{NCI}$ & $\begin{array}{l}\text {-Estimating the GCA of male and for the } \\
\text { female within male variances, and gene effects } \\
\text {-Applicable for the evaluation of } \\
\text { full and half sib recurrent selection } \\
\text {-Applicable to both self- and cross-pollinated } \\
\text { crops }\end{array}$ & $\begin{array}{l}\text {-No maternal effects } \\
\text {-No epistasis test } \\
\text {-Requires sufficient seed for replicated } \\
\text { evaluation trials }\end{array}$ & 107,109 \\
\hline & NC 2 & $\begin{array}{l}\text {-Estimating the combing ability } \\
\text { of parents and gene effects } \\
\text {-Has greater precision compared with NC I } \\
\text {-More applicable to self-pollinated crops }\end{array}$ & $\begin{array}{l}\text {-No maternal effects } \\
\text {-No epistasis test } \\
\text {-More adapted to plants with multiple } \\
\text { flowers }\end{array}$ & 108,109 \\
\hline & NC 3 & $\begin{array}{l}\text {-Estimating the combing ability } \\
\text { of parents and gene effects } \\
\text {-Provides test of epistatic interactions } \\
\text {-Has a general utility for investigating any } \\
\text { population irrespective of gene frequency or } \\
\text { mating system }\end{array}$ & & 108,109 \\
\hline
\end{tabular}

\section{Applications of combining ability in plant breeding}

In this section, we describe the main uses of combining ability in plant breeding, with an emphasis on important traits. We have classified these traits into four groups: yield and yield components, nutritional values, antioxidant properties, and pest resistance, although there may be overlap between these categories.

\section{Combining ability for yield}

The grain yield is a polygenically controlled trait and depends on large number of other related traits. Selection on the basis of grain yield alone is usually not effective, whereas selection along with its component characters could be more effective and reliable. ${ }^{33}$ The importance of additive gene effects for grain yield in maize, ${ }^{21-24}$ wheat, ${ }^{2,9,10,41}$ sorghum, ${ }^{43}$ sunflower, ${ }^{30,31}$ and cowpea ${ }^{33}$ has been reported (Table 1). Makumbi et al., ${ }^{22}$ reported that the variances for GCA effects became relatively more important than the variance for SCA effects when the maize inbred lines used under tests had been subjected to low nitrogen and drought conditions. In autotetraploids such as alfalfa, both additive and dominance variance can contribute to GCA effects since two alleles are transferred via parental gametes to progenies. ${ }^{110}$ However, SCA estimates include a much greater proportion of the dominance variance associated with diallelic, triallelic, and tetraallelic effects and their interactions. The predominance of GCA in determining forage yield of alfalfa has been documented. ${ }^{34-37}$ Upon examining the off spring of the populations involved in these studies, it was found that SCA effects can be detected via crossing genetically distinct genotypes and geographically distant population. ${ }^{36}$ However, most workers have reported greater relative importance of nonadditive genetic effects than additive genetic effects for grain yield in maize, ${ }^{23}$ rice,${ }^{38,40}$ sorghum, ${ }^{44-45}$ sunflower, ${ }^{32}$ rye,${ }^{46}$ tomato,${ }^{50}$ and linseed. ${ }^{52}$ For example, in a study by Dehghanpour \& Ehdaie, ${ }^{14}$ SCA effects were considered for more than $74 \%$ of the sum of squares among the hybrids. Moterle et al., ${ }^{27}$ and Singh et al., ${ }^{47}$ also verified that the nonadditive effect was proportionally of greater importance in the expression of the seed quality and total fruit yield in popcorn and hot pepper, respectively (Table 1). These differences indicate the importance of both additive and nonadditive gene action in the control of grain yield. 
There are several instances where the importance of both additive and nonadditive types of gene action for yield components was reported. ${ }^{12-14,16,21,38,40,47,50,51}$ In the first instance, the estimate of combining ability for grain weight, tabulated in Table 1 exhibited that nonadditive genetic variance accounted for a major portion of the genetic variation for this trait in rice, ${ }^{40}$ wheat, ${ }^{41-43}$ chickpea,,${ }^{16}$ and linseed.$^{52}$ It was indicated also by El-Gabry et al., ${ }^{50}$ that nonadditive gene effects contribute towards governing fruit weight in tomato. However, the findings of Shukla \& Pandey ${ }^{38}$ for grain weight in rice illustrated that additive gene effects was found to be more important than nonadditive gene effects in the inheritance of this character.

Grain yield is a quantitative trait which is affected by genotype $x$ environment $(\mathrm{G} \times \mathrm{E})$ hence combining ability would depend on the set of germplasm and environment where they are tested. Significant interactions were found between the environment and GCA in sorghum,${ }^{44}$ linseed, ${ }^{52}$ cotton, ${ }^{19}$ and maize,,${ }^{14,22}$ and also environment and SCA ${ }^{14,44,52}$ which infers that the rankings of both GCA and SCA changed across different environments and therefore selection would be more effective when based on performance across environments.

\section{Combining ability for nutritional value}

Improvement of oil quantity and quality in oleaginous crops is the major goal of breeding programs. In a diallel study of safflower, Golkar et al., ${ }^{48}$ found that nonadditive genetic variance accounted for a major proportion of the genetic variation for oil content and protein content ${ }^{49}$ with higher values in $\mathrm{F}_{2}$ generation than in $\mathrm{F}_{1}$. He suggested no genetic reason for this finding except low sample size and sampling variation within $F_{2}$ populations. However, this is in discordant with those obtained by Banerjee \& Kole $^{49}$ for sesame and Joshi et al., ${ }^{41}$ on bread wheat. Chigeza et al., ${ }^{30}$ evaluated the combining ability of field sunflower for oil yield and its components and showed that additive effects were the most important for seed yield and oil yield ${ }^{51}$ whilst for oil content both GCA and SCA effects appear to be important, with SCA effects having more influence than GCA..$^{31,52}$ Contrary to their results, Ortis et al., ${ }^{32}$ and Blank et al., ${ }^{51}$ observed that additive genetic effects had a larger influence on the oil content. Similar trend was found for fatty acids including linoleic, oleic, and palmitic acids. ${ }^{41,48}$ Machida et al., ${ }^{64}$ evaluated quality protein maize (QPM) diallel cross and found the preponderance of GCA effects for tryptophan content, protein content, kernel endosperm modification, while SCA effects were for Quality Index and anthesis dates.

\section{Combining ability for antioxidant properties}

Natural coloured pigments from plant products are made up of various phytochemicals generally found in the food matrix such as carotenoids and $\beta$-carotene. Diets comprising carotenoid rich grains, fruits, and vegetables are related with reduced risk of chronic diseases. ${ }^{111-112} \mathrm{Li}$ et al., ${ }^{25}$ and Egesel et al. ${ }^{26}$ verified that the additive effect was proportionally of greater importance in the expression of the $\beta$-carotene and carotenoids in maize, respectively. However, Dey et al., ${ }^{29}$ observed that nonadditive genetic effects had a larger influence on the $\beta$-carotene and carotenoids content in cauliflower. Artemisia апnиа is an important medicinal crop used for the production of the anti-malarial compound artemisinin. Townsend et al., ${ }^{28}$ studied combining ability with respect to artemisinin quality in 30 Artemisia апnиа lines using a complete diallel cross including reciprocals and found significant GCA values in artemisinin concentration and biomass.

\section{Combining ability for pest resistance}

Both additive and nonadditive gene effects were found important in governing pest resistance (including disease, insect and nematodes resistance, and parasitic weeds) in crops of greatest commercial interest including maize, wheat, and sunflower Table 5. In a diallel study involving $45 \mathrm{~F}_{1}$ hybrids evaluated over three years and two environments, Yallou et al., ${ }^{113}$ showed that negative GCA effects were more important than SCA effects in the control of the inheritance of the number of emerged Striga plants in maize Table 5. It corroborates other studies for resistance to northern leaf blight in maize, ${ }^{77,114}$ gray leaf spot in maize, ${ }^{77}$ stem canker in sunflower (Phomopsis helianthi $){ }^{11}$ Fusarium root rot in common bean, ${ }^{115}$ cassava brown streak in cassava, ${ }^{6}$ root-lesion nematodes (Pratylenchus thornei and P. neglectus) in wheat, ${ }^{116}$ and P. zeae and Meloidogyne spp. nematodes density in maize ${ }^{76}$ but differ from recent study by Akinwale et al., ${ }^{92}$ who found a greater manifestation of SCA in control of the number of emerged Striga plants under Striga infestation in maize Table 5. Recently, Derera et al., ${ }^{101}$ found maize weevil resistance to be under the control of both GCA and SCA effects. According to Bookmyer et al., ${ }^{117}$ and Mukankusi et al., ${ }^{115}$ negative GCA and SCA effects are preferable for disease resistance, on the basis of a scale where the highest value is associated with more disease attack.

Table 5 Combining ability for pest resistance

\begin{tabular}{|c|c|c|c|c|c|}
\hline Crop Species & Experimental Material & Type of Cross & GCA Dominance & SCA Dominance & References \\
\hline Maize (Zea mays L.) & 10 advanced inbred lines & Half diallel & $\begin{array}{l}\text { Northern leaf blight } \\
\text { disease severity, grain } \\
\text { yield }\end{array}$ & & 114 \\
\hline Maize (Zea mays L.) & 10 inbred lines & Diallel & $\begin{array}{l}\text { Number of emerged } \\
\text { Striga plants, host } \\
\text { damage score, grain yield }\end{array}$ & $\begin{array}{l}\text { Host damage score, } \\
\text { grain yield }\end{array}$ & 113 \\
\hline Maize (Zea mays L.) & 18 inbred lines & $\mathrm{NCll}$ & Grain weevil resistance & $\begin{array}{l}\text { Grain weevil } \\
\text { resistance }\end{array}$ & 101 \\
\hline Maize (Zea mays L.) & 28 inbred lines & Diallel & $\begin{array}{l}\text { Grain yield, ears per } \\
\text { plant, ear aspect, and } \\
\text { Striga damage rating }\end{array}$ & $\begin{array}{l}\text { Number of emerged } \\
\text { Striga plants, plant } \\
\text { height, anthesis- } \\
\text { silking interval, and } \\
\text { stalk lodging }\end{array}$ & 92 \\
\hline
\end{tabular}




\begin{tabular}{|c|c|c|c|c|c|}
\hline Crop Species & Experimental Material & Type of Cross & GCA Dominance & SCA Dominance & References \\
\hline wheat (Triticum aestivum L.) & $\begin{array}{l}5 \text { synthetic hexaploid } \\
\text { wheats crossed to the } \\
\text { susceptible Australian } \\
\text { wheat cultivar Janz }\end{array}$ & Diallel & $\begin{array}{l}\text { Resistance to root-lesion } \\
\text { nematodes (Pratylenchus } \\
\text { thornei and P. neglectus) }\end{array}$ & & 116 \\
\hline $\begin{array}{l}\text { Sunflower (Helianthus } \\
\text { annuus) }\end{array}$ & $\begin{array}{l}6 \text { male sterile sunflower } \\
\text { lines were crossed with } 7 \\
\text { restorers }\end{array}$ & Factorial design & $\begin{array}{l}\text { Resistance to stem } \\
\text { canker }\end{array}$ & & 11 \\
\hline $\begin{array}{l}\text { Common bean (Phaseolus } \\
\text { vulgaris L.) }\end{array}$ & $\begin{array}{l}12 \text { bean cultivars } \\
\text { comprising } 6 \text { resistant and } \\
6 \text { susceptible }\end{array}$ & $\begin{array}{l}12 \times 12 \text { full } \\
\text { diallel mating }\end{array}$ & $\begin{array}{l}\text { Resistance to Fusarium } \\
\text { root rot }(\mathrm{FI}, \mathrm{F} 2, \mathrm{~F} 3)\end{array}$ & $\begin{array}{l}\text { Resistance to } \\
\text { Fusarium root rot } \\
\text { (F3) }\end{array}$ & 115 \\
\hline $\begin{array}{l}\text { cassava (Manihot esculenta } \\
\text { Crantz) }\end{array}$ & $\begin{array}{l}2 \text { resistant and } 2 \\
\text { susceptible varieties }\end{array}$ & Half diallel & $\begin{array}{l}\text { Resistance to Cassava } \\
\text { brown streak disease }\end{array}$ & $\begin{array}{l}\text { Resistance to } \\
\text { Cassava brown } \\
\text { streak disease }\end{array}$ & 6 \\
\hline $\begin{array}{l}\text { Button mushroom (Agaricus } \\
\text { bisporus) }\end{array}$ & 19 homokaryotic lines & $\begin{array}{l}\text { Incomplete set } \\
\text { of Diallel }\end{array}$ & Bruising resistance & Bruising resistance & 118 \\
\hline
\end{tabular}

GCA: General Combining Ability; NC: North Carolina Design; SCA: Specific Combining Ability

\section{Combining ability and germplasm classification}

One of the most important applications of combining ability is assignment of plant genotypes into heterotic groups which form the basis of productive hybrid programs. A heterotic group is a group of plant genotypes which are related or not related. The genotypes might come from the same or different populations. Genotypes from the same heterotic group show similar behaviour with respect to combining ability and heterosis when crossed with other genotypes from genetically divergent groups. The diallel and line $\times$ tester mating schemes can be used to establish heterotic groups for unknown genotypes such as new introductions in hybrid programs. Librando \& Magulama $^{119}$ demonstrated the usefulness of combining ability effects in classifying maize inbred lines into heterotic groups. Previously Fan et al., ${ }^{120}$ studied 25 lines from CIMMYT populations using combining ability analysis and concluded that eight exotic lines were genetically similar to the testers and could be assigned to the two current maize heterotic groups. Fato et al., ${ }^{121}$ established heterotic groups of lowland Mozambican maize inbred lines using broad-based populations ZM523 and Suwan- 1 as testers in a line $\times$ tester mating scheme under downy mildew infestation. Kanyamasoro et al., ${ }^{122}$ studied combining ability among maize weevil resistant inbred lines and used specific combining ability (SCA) data to classify 23 inbred lines to heterotic Group A, 24 to Group B, and 5 to both A and B.

\section{Assumptions for mating designs and implications}

There are some assumptions underlying diallel, line $\times$ tester and North Carolina mating designs. These assumptions have been discussed by Baker, ${ }^{63}$ Hallauer \& Miranda, ${ }^{58}$ Christie \& Shattuck, ${ }^{80}$ and Dabholkar ${ }^{81}$ among other authorities. They should be validated or acknowledged when interpreting results from genetic studies. The assumptions are as follows:

I. Random choice of individuals mated for production of experimental progenies. This depends on the model of choice. When a random model is used, parents for crossing should be selected at random, such that every parent in the population has an equal chance of participating in the crossing scheme. For a fixed model, parents for crossing are selected based on special criteria. For example a set of disease resistant and a set of susceptible parents can be selected for use in diallel or NCDII crossing; an established line is chosen as a tester for a selected set of lines, or a set of diverse lines is chosen for crossing to maximise chances of getting crosses with high heterosis and high combining ability.

II. Random distribution of genotypes relative to variations in the environment. The experimental errors are independent. Presumably there is no $\mathrm{G} \times \mathrm{E}$ interaction for the trait(s) under consideration. This can be validated by evaluating diallel, North Carolina, and line $\times$ tester crosses in a minimum of three environments with at least two replications coupled with randomisation in each environment to accumulate at least a total of six degrees of freedom. This provides a fair estimate of the role of $\mathrm{G} \times \mathrm{E}$ interactions in conditioning combining ability.

III. Absence of non-genetic maternal effects. If present, significant maternal effects would lead to the upward bias of the additive variance [58]. This gives a false impression of magnitude of GCA effects and heritability. The problem of maternal effects can be validated in a diallel mating by including reciprocal or 
reverse crosses (see Griffings Method I and III). An advantage of NCDII over the diallel in this respect is that it provides two independent estimates of GCA-one based on the male and the other on female parents, thus giving two estimates of additive variance. Consequently heritability can be calculated from the male source which is free from maternal effects. When data is balanced, ratio of male to female mean squares can be used to estimate role of maternal effects in a NCDII mating scheme. Maternal and reciprocal effects have been reported to be important for the following traits: grain weevil resistance in maize, ${ }^{101,102,123}$ Quality Index, tryptophan, and anthesis dates in quality protein maize [64]. Using NCDII mating, Derera et al., ${ }^{103}$ reported that contributions of male GCA (GCAm) and female GCA (GCAf) effects to maize hybrids varied depending on the trait and conditions. They found superior GCAf to GCAm effects for yield under drought conditions, and for anthesis to silk emergence interval, ear prolificacy and ear aspect under both drought and non-drought conditions, suggesting that the traits were modified by maternal effects. In a diallel evaluation of ear rot disease severity in maize, Mukanga et al., ${ }^{124}$ reported highly significant reciprocal effects indicating that cytoplasmic effects played a significant role in modifying ear rot resistance in maize hybrids. However, Nkalubo et al., ${ }^{125}$ found that reciprocal effects accounted for $10 \%$ of the variation and were not significant $(\mathrm{P}$ $>0.05$ ), suggesting that cytoplasmic genes did not play a major role in modifying anthracnose resistance in common beans.

IV. Regular diploid behaviour at meiosis. It is assumed that crop species under study is a diploid or acts in a diploid manner during meiosis, for example polyploids with an even number of chromosome sets, such as tetraploids and hexaploids.

V. No multiple alleles. Application of the designs assumes that traits under study are not under multiple allele influence.

VI. No linkage except where equilibrium between coupling and repulsion phases exists. Genes controlling traits under consideration are not correlated, not linked, and undergo independent assortment during meiosis. If there is linkage, then the repulsion and coupling phase linkage are in equilibrium.

VII. No epistasis. According to Baker ${ }^{63}$ the assumption, that there is no epistasis, may frequently be incorrect. Epistasis affects estimates of general and specific combining ability mean squares, variances, and effects in an unpredictable manner. The role of epistasis has not been validated in many studies of combining ability. However the role of epistasis can be tested by using Hayman's analysis for the diallel. A study by Nkalubo et al., ${ }^{125}$ was not conclusive on whether epistatic gene action played a major role in conditioning anthracnose resistance in common beans, but if available it might have biased the dominance gene effects. Simulation of two-locus genetic models was used to investigate the effects of gene frequency, non-random association of genes, and epistasis on the interpretation of diallel experiments in selfpollinating crops. It was demonstrated that general combining ability includes effects due to additive, epistatic, and, when gene frequencies are not equal to 0.5 , dominance gene action. Similarly, when gene frequencies do not equal 0.5 , average heterosis depends upon additive $\times$ dominance interaction as well as dominance and dominance $\times$ dominance interaction. Negative associations between genes greatly inflate the apparent amount of specific combining ability. These findings cast serious doubt on the utility of diallel analysis for studying the genetics of selfpollinating crops.
VIII. Independent distribution of genes. In diallel cross, the assumption concerning the independent distribution of genes in the parents is most critical to proper interpretation and seems to be least acceptable in actual practice. ${ }^{63}$

\section{QTL mapping}

The ability to predict optimal genotype combinations for various goals in plant breeding on the basis of molecular-based genetic data would remarkably increase the effectiveness of plant breeding programs. The first attempt to use the genetic basis behind combining ability was performed by Griffing. ${ }^{71}$ He suggested the use of the mating design and diallel to partition the genetic variance into $\delta_{\mathrm{GCA}}^{2}$ and $\delta_{\text {SCA }}^{2}$ and estimated the GCA effect.

Theoretically, when GCA is considered as a trait, all populations for QTL mapping can be applied to map GCA loci. However, populations such as $\mathrm{F}_{2}, \mathrm{~F}_{2: 3}$, and $\mathrm{BC}_{1}$, segregate at the whole genome level (are heterozygous at most loci) and when used, repeated observations cannot be made at the level of individual or block and inhibit multiple trials conduction. Two alternative ways are used to allow the repeated detection of non-additive effects by the creation of heterozygotes from permanent populations: 1) to develop heterozygotes by testcrosses (TC) or backcrosses (BC) from a recombinant inbred (RI) population, $\left.{ }^{127-129,2}\right)$ to generate an immortalized $\mathrm{F}_{2}$ population through inter-mating between the RILs. ${ }^{130,131}$ In the first, the genotype of a hybrid is developed from the genotypes of the parental lines. Gene actions can be determined to be particularly additive or non-additive through comparing QTLs mapped in RILs and their TC hybrid populations. ${ }^{132}$ In back cross hybrids, the genotype of each hybrid is known at each locus, however in TC populations, the homology between alleles from parental RILs and the tester is unclear. It is shown that an unrelated elite-line tester is as efficient as the related low performance testers. ${ }^{133}$ Frascaroli et al. ${ }^{134}$ compared QTL detection on related and unrelated testcross progenies and concluded that for traits with dominance effects, such as grain yield and number of kernels per plant, the poorly performing related inbred was the most effective tester. In contrast, unrelated inbred was more effective for traits characterized by prevailing additive gene action such as days to pollen shedding, plant height, kernel moisture and kernel weight, than related inbred lines. The accuracy of GCA measurement of tested inbred lines is of the outmost importance for increasing the power of GCA QTL mapping. LV et al., ${ }^{8}$ examined the feasibility of GCA QTL mapping and reported that mapping GCA can be achieved using various genetic populations including BCRILs and introgression lines (ILs) in maize. Out of 69 QTLs identified for grain yield and yield associated traits (38 in the ILs and 63 in the testcross populations), only 9 loci were detected for GCA on 5 chromosomes of maize (Table 6). Their results showed that the genetic control of GCA is completely different from that of yield traits of inbred lines. Moreover, Qi et al., ${ }^{135}$ identified 56 significant QTL ${ }^{\mathrm{GCA}}$ loci for five yield-related traits in maize using a set of testcrosses with ILs under different environmental conditions. They also found a significant correlation between the number of significant GCA loci in the ILs and the performance of GCA.

Recombinant inbred lines and double haploids (DH) are considered as valuable populations for QTL mapping, owing to the high homozygosity level of each individual and homogeneity within each line. ${ }^{25,136}$ High homozygosity level results in a higher $\delta^{2}{ }_{\mathrm{GCA}}$ estimate compared with segregating populations results, whilst dominance and dominance interaction are removed. For example, in a RILs population, $\delta^{2}{ }_{\mathrm{GCA}}$ is expected to be twice as much as that of a $\mathrm{F}_{2 \cdot 3}$ population. In turn, this higher genetic variance should result in a higher heritability, and thus to be more potent QTL detection. ${ }^{137}$ 
This was the case in the study of Austin et al., ${ }^{138,139}$ who identified more QTL in the $\mathrm{F}_{6: 8}$ population than in the $\mathrm{F}_{2: 3}$ population developed from the same source. In another study by Li et al., ${ }^{25}$ the power of QTL mapping for GCA ranked in the order of DH (RIL) based $>$ $\mathrm{F}_{2}$ based $>\mathrm{BC}$ based NCII design, when the heritability was low (Table 6). In testcross progeny, the dominance variance which greatly influences the phenotype of hybrids is predominantly derived from the allelic difference between the tested line and the tester, and a sum of interactions among heterozygous loci. Furthermore, these dominance variances will certainly minimize the power of GCA locus identification. Meanwhile, Qu et al., ${ }^{12}$ identified a large number of additive effects of QTL ${ }^{\mathrm{GCA}}$ loci for ten agronomic traits in rice using RIL populations with three testers in three testcross populations and a backcross recombinant inbred line (BCRIL) population. Using simple sequence repeat markers (SSR) aid selection, Liu et al., ${ }^{140}$ improved GCA of the elite restorer line, Minhui63 in rice. Belicuas et al., ${ }^{141}$ identified four QTLs with additive effect and concluded that additive effects were more important than dominance effects in the inheritance of the stay-green trait in maize (GCA/SCA of 6.41). In a study by Huang et al., ${ }^{142}$ among sixteen loci identified for the GCA of yield per plant, only bnlg1017 was detected in two environments. At this locus, the allele from the donor parent enhanced the GCA of yield per plant by 3.27-3.89 g across various environments. Li et al., ${ }^{143}$ applied NCDIII to RILs in highly heterotic inter- and intra-subspecific hybrids of rice. QTL analysis identified 20 QTLs (41.7\%) with additive effects, $20(41.7 \%)$ with partial-to-complete dominance, and
$8(16.7 \%)$ with overdominance effects in inter-subspecific hybrids. In intra-subspecific hybrids, 34 QTLs (51.5\%) exhibited additive effects, $14(21.2 \%)$ partial-to-complete dominance, and $18(27.3 \%)$ overdominance.

Near isogenic line (NIL) and single segment introgression line (SSIL) populations are more proper for cloning and fine gene mapping, because of their comparatively clear and simple genetic backgrounds.

Li et al., ${ }^{25}$ averred that growth in sample size and broad heritability could increase the QTL detection power for GCA. However, growth in tester number could not increase the QTL detection power. ${ }^{144,145}$ In a study by $\mathrm{He}$ et al. ${ }^{144}$ increase in sample size from 100 to 400 resulted in dramatic increase in QTL detection power. Marker assisted selection (MAS) has been viewed as a promising approach in plant breeding. The successful pyramiding of desired genes associated with combining ability by MAS, resulting in enhanced combining ability of the selected lines of rice, was illustrated by Liu et al., ${ }^{140}$ In a study by Stuber, ${ }^{146}$ using MAS, the QTLs related to maize grain yield were transferred successfully. As a consequence the testcross performance was improved. For a better contribution of marker-QTL associations in plant breeding, their association should be consistent across diverse genetic backgrounds of inbred line testers and across breeding populations within a heterotic group. ${ }^{147}$ As a result, a masking effect of the tester allele is involved in inconsistent QTL results among testers. $^{25}$

Table 6 QTL mapping for GCA and SCA

\begin{tabular}{|c|c|c|c|c|c|c|c|c|}
\hline $\begin{array}{l}\text { Population/ } \\
\text { Type }\end{array}$ & Parents & Chromosome & $\begin{array}{l}\text { Marker } \\
\text { Interval }\end{array}$ & Loci & $\mathbf{R 2} \%$ & $\begin{array}{l}\text { Allele } \\
\text { for the } \\
\text { Increased } \\
\text { GCA Effect }\end{array}$ & $\begin{array}{l}\text { Allele } \\
\text { for the } \\
\text { Increased } \\
\text { SCA Effect }\end{array}$ & Reference \\
\hline \multicolumn{9}{|l|}{ Maize } \\
\hline $\begin{array}{l}75 \text { lines and } \\
\text { four testers } \\
\text { (ILs) }\end{array}$ & $\begin{array}{l}\text { Ye478 (elite } \\
\text { inbred)/Qi319 } \\
\text { (elite inbred) }\end{array}$ & 2 & $\begin{array}{l}\text { umc| } 227 \text { - } \\
\text { umc | } 980\end{array}$ & bnlg1017 & $\begin{array}{l}\text { I I.82, } 9.12 \text { (two } \\
\text { environments) }\end{array}$ & Qi319 & & 141 \\
\hline \multirow[t]{4}{*}{ F2 plants } & $\begin{array}{l}\text { L-I4-04B (elite } \\
\text { inbred)/ L-08-05F } \\
\text { (elite inbred) }\end{array}$ & 3 & $\begin{array}{l}\text { umc| } 659 \text { - } \\
\text { umc| } 320\end{array}$ & $\operatorname{Stg} 3 b$ & 3.21 & L-08-05F & & 140 \\
\hline & & 4 & $\begin{array}{l}\text { bnlg0252 - } \\
\text { bnlg229l }\end{array}$ & Stg $4 c$ & 8.36 & & Stg $4 c$ & \\
\hline & & 6 & $\begin{array}{l}\text { phi0126 - } \\
\text { bnlgI37I }\end{array}$ & Stg6 & 3.76 & L-08-05F & & \\
\hline & & 9 & $\begin{array}{l}\text { bnlg0430 - } \\
\text { umc I I07 }\end{array}$ & Stg9 & 3.8 & L-08-05F & & \\
\hline \multirow[t]{3}{*}{$\begin{array}{l}75 \text { ILs lines and } \\
\text { four testers }\end{array}$} & $\begin{array}{l}\text { Zong 3(elite } \\
\text { inbred)/ } \\
\text { HB522(wax } \\
\text { inbred) }\end{array}$ & 1 & $\begin{array}{l}\text { umc2390 - } \\
\text { umc2229 }\end{array}$ & umc I 770 & $\begin{array}{l}\text { I. } 09,0.67 \\
\text { (two } \\
\text { environments) }\end{array}$ & HB522 & & 135 \\
\hline & & 2 & $\begin{array}{l}\text { bnlg| } 496 \text { - } \\
\text { umc|052 }\end{array}$ & $\mathrm{mmc000I}$ & $9.07,3.84$ & & HB522 & \\
\hline & & 3 & $\begin{array}{l}\text { umc|404 - } \\
\text { bnlg |779 }\end{array}$ & umc I 825 & $7.23,9.85$ & & HB522 & \\
\hline
\end{tabular}


Table Continued

\begin{tabular}{|c|c|c|c|c|c|c|c|c|}
\hline $\begin{array}{l}\text { Population/ } \\
\text { Type }\end{array}$ & Parents & Chromosome & $\begin{array}{l}\text { Marker } \\
\text { Interval }\end{array}$ & Loci & $\mathbf{R 2} \%$ & $\begin{array}{l}\text { Allele } \\
\text { for the } \\
\text { Increased } \\
\text { GCA Effect }\end{array}$ & $\begin{array}{l}\text { Allele } \\
\text { for the } \\
\text { Increased } \\
\text { SCA Effect }\end{array}$ & Reference \\
\hline
\end{tabular}

Maize

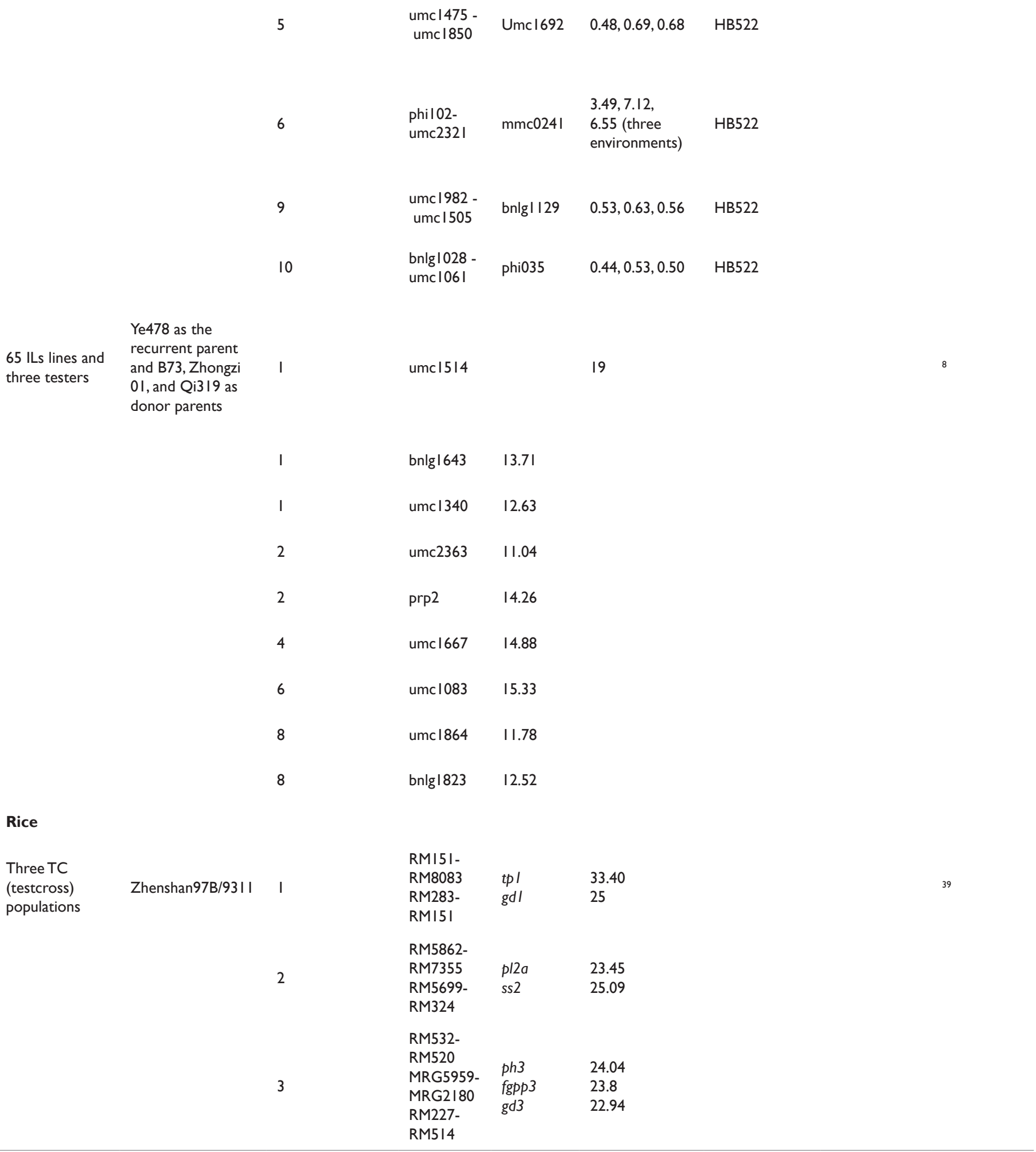


Table Continued

\begin{tabular}{|c|c|c|c|c|c|c|c|c|}
\hline $\begin{array}{l}\text { Population/ } \\
\text { Type }\end{array}$ & Parents & Chromosome & $\begin{array}{l}\text { Marker } \\
\text { Interval }\end{array}$ & Loci & $\mathbf{R} 2 \%$ & $\begin{array}{l}\text { Allele } \\
\text { for the } \\
\text { Increased } \\
\text { GCA Effect }\end{array}$ & $\begin{array}{l}\text { Allele } \\
\text { for the } \\
\text { Increased } \\
\text { SCA Effect }\end{array}$ & Reference \\
\hline
\end{tabular}

Maize

5

$\begin{array}{lll}\text { RM440- } & \text { ss5 } & 27.53\end{array}$

6

RM589-

RM584

RMI2I- tp6 23.97

$\begin{array}{lll}\text { RM607I pl6 } & 56.17\end{array}$

RMI2I- $\quad$ gpp6 $\quad 58.73$

$\begin{array}{lll}\text { RM607I } & \text { spp6 } & \text { I7.84 }\end{array}$

RM3|4-

RM50

RM3583-

RM7II0

RMI253- ph7 25.19

7

$\begin{array}{ll}h d 7 & 24.18\end{array}$

$\begin{array}{lll}\text { RM3583- } & \text { pl7 } & 21.45\end{array}$

RM7IIO

RM25-

$\begin{array}{lll}\text { MRG2I8I ph8 } 25.53 & \end{array}$

8

$\begin{array}{lll}\text { RM25- } & p h 8 & 25.53 \\ \text { MRG2I8I } & h d 8 & 21.65\end{array}$

$\begin{array}{lll}\text { MRG2I8I } & \text { pl8 } & 31.65 \\ \text { RMI52 } & 31.05\end{array}$

MRG0270

RM3717-

RMI9 $\quad$ ph/2

194 F7 RILs

derived from 9024 (indica)/

inter-subspecific LH422 (japonica)

RG375

CDO348

hdla

(I)

3

RZ993-

CDOI08I hd3b

7

$\begin{array}{lll}\text { CDO553- } & \text { hd7b } & \\ \text { RG528 } & \end{array}$

8

RG333-

RZ562

hd8

63.19

I I

$\begin{array}{lll}\text { RZ536- } & \text { hdl la } & 2.42\end{array}$

2

XNPBI32-
RG544

11.23

RZ965-

CDO544 ph6

RG333-

RZ562

ph8

17.83

RG2 |4-

CDO539

tp4

11.89

RZ562-

RZ66

tp8

7.77 
Table Continued

\begin{tabular}{|c|c|c|c|c|c|c|c|c|}
\hline $\begin{array}{l}\text { Population/ } \\
\text { Type }\end{array}$ & Parents & Chromosome & $\begin{array}{l}\text { Marker } \\
\text { Interval }\end{array}$ & Loci & $\mathbf{R 2} \%$ & $\begin{array}{l}\text { Allele } \\
\text { for the } \\
\text { Increased } \\
\text { GCA Effect }\end{array}$ & $\begin{array}{l}\text { Allele } \\
\text { for the } \\
\text { Increased } \\
\text { SCA Effect }\end{array}$ & Reference \\
\hline
\end{tabular}

Maize

\begin{tabular}{|c|c|c|c|c|c|c|}
\hline & & 3 & $\begin{array}{l}\text { RZ993- } \\
\text { CDOI08I }\end{array}$ & $p / 3$ & 4.82 & \\
\hline & & 5 & $\begin{array}{l}\text { RZ495- } \\
\text { RZ70 }\end{array}$ & pl5a & 5.23 & \\
\hline & & 3 & $\begin{array}{l}\text { RZ993- } \\
\text { CDOI08I }\end{array}$ & fgpp3 & II.I4 & \\
\hline & & 4 & $\begin{array}{l}\text { RG2I4- } \\
\text { CDO539 }\end{array}$ & fgpp4a & 32.01 & \\
\hline & & 5 & $\begin{array}{l}\text { RG360- } \\
\text { RZ296 }\end{array}$ & fgpp5b & 8.43 & \\
\hline & & 3 & $\begin{array}{l}\text { RZ993- } \\
\text { CDOI08I }\end{array}$ & ss 3 & 5.35 & \\
\hline & & 5 & $\begin{array}{l}\text { RG360- } \\
\text { RZ296 }\end{array}$ & ss 5 & II.67 & \\
\hline & & 3 & $\begin{array}{l}\text { RZI6- } \\
\text { RZ993 }\end{array}$ & $g d 3 a$ & 6.71 & \\
\hline & & 4 & $\begin{array}{l}\text { RGI43- } \\
\text { RZ590 }\end{array}$ & gd4 & 20.9 & \\
\hline & & 6 & $\begin{array}{l}\text { RGI028- } \\
\text { RGI62 }\end{array}$ & gd6 & 3.85 & \\
\hline & & 10 & $\begin{array}{l}\text { RZ56I- } \\
\text { RZ400 }\end{array}$ & $\mathrm{gd} / 0$ & 8.29 & \\
\hline & & 4 & $\begin{array}{l}\text { RG908- } \\
\text { RZ602 }\end{array}$ & kgw4 & I4.45 & \\
\hline & & 7 & $\begin{array}{l}\text { RG528- } \\
\text { RG4I7 }\end{array}$ & kgw7 & 3.82 & \\
\hline & & 8 & $\begin{array}{l}\text { RG333- } \\
\text { RZ562 }\end{array}$ & kgw8 & 22.4 & \\
\hline & & 3 & $\begin{array}{l}\text { RZ993- } \\
\text { CDOI08I }\end{array}$ & $y d 3$ & 6.48 & \\
\hline & & 5 & $\begin{array}{l}\text { RZ556- } \\
\text { RG360 }\end{array}$ & $y d 5$ & 5.22 & \\
\hline & & 6 & $\begin{array}{l}\text { RG653- } \\
\text { RZ828 }\end{array}$ & yd6a & 4.17 & \\
\hline & & 7 & $\begin{array}{l}\text { XNPB20- } \\
\text { RZ509 }\end{array}$ & $y d 7$ & $|4.8|$ & \\
\hline & & 8 & $\begin{array}{l}\text { RG333- } \\
\text { RZ562 }\end{array}$ & $y d 8$ & 21 & \\
\hline $\begin{array}{l}222 \text { FI2 } \\
\text { RILs from } \\
\text { intrasubspecific }\end{array}$ & $\begin{array}{l}\text { Zhenshan97 } \\
\text { (indica)/Minghui63 } \\
\text { (indica) }\end{array}$ & 2 & $\begin{array}{l}\text { RM208- } \\
\text { RM207 }\end{array}$ & $h d 2$ & 6.34 & 142 \\
\hline
\end{tabular}


Table Continued

\begin{tabular}{|c|c|c|c|c|c|c|c|c|}
\hline $\begin{array}{l}\text { Population/ } \\
\text { Type }\end{array}$ & Parents & Chromosome & $\begin{array}{l}\text { Marker } \\
\text { Interval }\end{array}$ & Loci & $\mathbf{R 2} \%$ & $\begin{array}{l}\text { Allele } \\
\text { for the } \\
\text { Increased } \\
\text { GCA Effect }\end{array}$ & $\begin{array}{l}\text { Allele } \\
\text { for the } \\
\text { Increased } \\
\text { SCA Effect }\end{array}$ & Reference \\
\hline
\end{tabular}

Maize

\begin{tabular}{|c|c|c|c|}
\hline 6 & $\begin{array}{l}\text { RZ398- } \\
\text { RM204 }\end{array}$ & ph6b & 9.2 \\
\hline 10 & $\begin{array}{l}\text { RM258- } \\
\text { RG56I }\end{array}$ & phlo & 3.29 \\
\hline I & $\begin{array}{l}\text { RM259- } \\
\text { RM243 }\end{array}$ & $t p / a$ & 7.7 \\
\hline 2 & $\begin{array}{l}\text { RI738- } \\
\text { RM53 }\end{array}$ & $t p 2 a$ & 8.46 \\
\hline II & $\begin{array}{l}\text { Y6854L- } \\
\text { RM224 }\end{array}$ & $t p / I$ & 10 \\
\hline 9 & $\begin{array}{l}\text { RM219- } \\
\text { RI687 }\end{array}$ & pl9 & 5.67 \\
\hline 6 & $\begin{array}{l}\text { RM204- } \\
\text { RIOI4 }\end{array}$ & fgpp6 & 10.67 \\
\hline 10 & $\begin{array}{l}\text { R2625- } \\
\text { RM228 }\end{array}$ & fgpp 10 & 13.13 \\
\hline 3 & $\begin{array}{l}\text { RM55- } \\
\text { RM200 }\end{array}$ & $s s 3 a$ & 18.48 \\
\hline 6 & $\begin{array}{l}\text { RM204- } \\
\text { RI0I4 }\end{array}$ & $s s 6 a$ & 9.91 \\
\hline II & $\begin{array}{l}\text { C794- } \\
\text { RGII8 }\end{array}$ & ss II & 9.18 \\
\hline 12 & $\begin{array}{l}\text { C996- } \\
\text { GII28a }\end{array}$ & $s s / 2 a$ & 5.8 \\
\hline 6 & $\begin{array}{l}\text { RM204- } \\
\text { RIOI4 }\end{array}$ & gd6a & 7.64 \\
\hline 9 & $\begin{array}{l}\text { RM20I- } \\
\text { C472 }\end{array}$ & gd9a & 5.56 \\
\hline 10 & $\begin{array}{l}\text { R2625- } \\
\text { RM228 }\end{array}$ & gdlo & 16.56 \\
\hline 2 & $\begin{array}{l}\text { RI738- } \\
\text { RM53 }\end{array}$ & kgw2 & 13.1 \\
\hline
\end{tabular}


Table Continued

\begin{tabular}{|c|c|c|c|c|c|c|c|c|}
\hline $\begin{array}{l}\text { Population/ } \\
\text { Type }\end{array}$ & Parents & Chromosome & $\begin{array}{l}\text { Marker } \\
\text { Interval }\end{array}$ & Loci & $\mathbf{R 2} \%$ & $\begin{array}{l}\text { Allele } \\
\text { for the } \\
\text { Increased } \\
\text { GCA Effect }\end{array}$ & $\begin{array}{l}\text { Allele } \\
\text { for the } \\
\text { Increased } \\
\text { SCA Effect }\end{array}$ & Reference \\
\hline
\end{tabular}

\section{Maize}

\begin{tabular}{|c|c|c|c|}
\hline & $\begin{array}{l}\text { RG393- } \\
\text { Cl087 }\end{array}$ & kgw3a & 8.98 \\
\hline & $\begin{array}{l}\text { RG360- } \\
\text { C734b }\end{array}$ & kgw5 & 5.51 \\
\hline & $\begin{array}{l}\text { R2869- } \\
\text { C474 }\end{array}$ & kgw6a & 11.95 \\
\hline & $\begin{array}{l}\text { RM2II- } \\
\text { RG634 }\end{array}$ & $y d 2 a$ & 4.24 \\
\hline
\end{tabular}

DH: Doubled Haploid Lines; RIL: Recombinant Inbred Lines; $\mathrm{F}_{2}-\mathrm{F}_{5}$ : Populations; BC: Backcross Population; Cssls: Chromosome Segment Substitution Lines; IL: Introgressed Lines; GCA: General Combining Ability; SCA: Specific Combining Ability

\section{Summary and Future Perspectives}

Although considerable progress has been made in crop improvement by plant breeding, it is essential that it continue. Through commonly applied breeding techniques, current breeding programmes continue to evolve. Combining ability could largely contribute in achieving this object. Combining ability as a considerable analysis tool is not only useful for selecting favourable parents but also provides information concerning the nature of and importance of gene effects influencing quantitative traits. In spite of hopefulness regarding sustained yield increase from conventional breeding, new approaches such as QTL mapping will be required to increase the likelihood of achievement. Further advances in marker technology may reduce the cost of QTL mapping and make it more applicable for combining ability programmes.

\section{Acknowledgement}

The authors received no specific funding for this article.

\section{Conflict of Interest}

The author declares no conflict of interest.

\section{References}

1. Oakey H, Verbyla A, Pitchford W, et al. Joint modeling of additive and non-additive genetic line effects in single field trials. Theoretical and Applied Genetics. 2016;113(5):809-819.

2. Topal A, Aydın C, Akgun N, et al. Diallel cross analysis in durum wheat (Triticum durum Desf.): identification of best parents for some kernel physical features. Field Crops Research. 2004;87:1-12.

3. Allard RW. Principles of Plant Breeding, John Wiley and Sons Inc, New York, USA; 1960.

4. Vasal SK, Cordova H, Pandey S, et al. Tropical maize and heterosis. CIMMYT research highlights, Mexico, DF, CIMMYT. 1986.

5. Sprague GF, Tatum LA. General versus specific combining ability in single crosses of corn. Journal of the American Society of Agronomy. 1942;34:923-932.
6. Kulembeka HP, Ferguson M, Herselman L, et al. Diallel analysis of field resistance to brown streak disease in cassava (Manihot esculenta Crantz) landraces from Tanzania. Euphytica. 2012;187(2):277-288.

7. Griffing B. A generalized treatment of the use of diallel crosses, in quantitative inheritance Heredity. Australian Journal of Biological Sciences. 1956a;10:31-50.

8. LV A, Zhang $\mathrm{H}$, Zhang Z, et al. Conversion of the statistical combining ability into a genetic concept. Journal of Integrative Agriculture. 012;11:43-52.

9. Bao Y, Wang S, Wang X, et al. Heterosis and combining ability for major yield traits of a new wheat germplasm Shannong 0095 derived from Thinopyrum intermedium. Agricultural Sciences in China. 2009;8(6):753-760.

10. Khaled AGA, Hamam KA, Motawea MH, et al. Genetic studies on tissue culture response and some agronomical traits in Egyptian bread wheat. Journal of Genetic Engineering and Biotechnology. 2013;11:79-86.

11. Deglene L, Alibert G, Lesigne P, et al. Inheritance of resistance to stem canker (Phomopsis helianthi) in sunflower. Plant Pathology. 1999;48(4):559-563.

12. Qu Z, Li L, Luo J, et al. QTL mapping of combining ability and heterosis of agronomic traits in rice backcross recombinant inbred lines and hybrid crosses. PLoS One. 2012;7(1):e28463.

13. Makanda I, Tongoona P, Derera J, et al. Combining ability and cultivar superiority of sorghum germplasm for grain yield across tropical lowand mid-altitude environments. Field Crops Research. 2010;116:75-85.

14. Dehghanpour Z, Ehdaie B. Stability of general and specific combining ability effects for grain yield in elite Iranian maize inbred lines. Journal of Crop Improvement. 2013;27(2):137-152.

15. Zeng L, Pettigrew WT. Combining ability, heritability, and genotypic correlations for lint yield and fiber quality of Upland cotton in delayed planting. Field Crops Research. 2015;171:176-183.

16. Bicer BT, Sakar D. Heritability and gene effects for yield and yield components in chickpea. Hereditas. 2008;145(5):220-224.

17. Bahari M, Rafii MY, Saleh GB, et al. Combining ability analysis in complete diallel cross of watermelon (Citrulluslanatus (Thunb.) Matsum. \& Nakai). Scientific World Journal. 2012;543158. 
18. Noh A, Rafii MY, Saleh G, et al. Genetic performance and general combining ability of oil palm Deli dura x AVROS pisifera tested on inland soils. The Scientific World Journal. 2012;792601:1-8.

19. Anandan A. Environmental impact on the combining ability of fiber traits and seed-cotton yield in cotton. Journal of Crop Improvemen. 2010;24(4):310-323.

20. Ertiro BT, Zeleke H, Friesen D, et al. Relationship between the performance of parental inbred lines and hybrids for food-feed traits in maize (Zea mays L.) in Ethiopia. Field Crops Research. 2013;153:86-93.

21. Pswarayi A, Vivek B. Combining ability amongst CIMMYT's early maturing maize (Zea mays L.) germplasm under stress and non-stress conditions and identification of testers. Euphytica. 2008;162(2):353-362.

22. Makumbi D, Betran FJ, Banziger M, et al. Combining ability, heterosis and genetic diversity in tropical maize (Zeamays L.) under stress and non-stress conditions. Euphytica. 2011;180(2):143-162.

23. Fan XM, Zhang YD, Yao WH, et al. Reciprocal diallel crosses impact combining ability, variance estimation, and heterotic group classification Crop Science. 2014;54(1):89-97.

24. Badu Apraku B, Annor B, Oyekunle M, et al. Grouping of early maturing quality protein maize inbreds based on SNP markers and combining ability under multiple environments. Field Crops Research 2015;183:169-183.

25. Li R, Xiao L, Wang J, et al. Combining ability and parent-offspring correlation of maize (Zea may L.) grain $\beta$-carotene content with a complete diallel. Journal of Integrative Agriculture. 2013;12(1):19-26.

26. Egesel CO, Wong JC, Lambert RJ, et al. Combining ability of maize inbreds for carotenoids and tocopherols. Crop Science. 2003;43:818823.

27. Moterle LM, Braccini AL, Scapim CA, et al. Combining ability of popcorn lines for seed quality and agronomic traits. Euphytica. 2012;185(3):337-347.

28. Townsend T, Segura V, Chigeza G, et al. The use of combining ability analysis to identify elite parents for Artemisia annua $\mathrm{F}_{1}$ hybrid production. PLoS One. 2013;8(4): e61989.

29. Dey SS, Singh N, Bhaatia R, et al. Genetic combining ability and heterosis for important vitamins and antioxidant pigments in cauliflower (Brassica oleracea var. botrytis L.). Euphytica. 2014;195(2):169-181.

30. Chigeza G, Mashingaidze K, Shanahan P. Advanced cycle pedigree breeding in sunflower. II: combining ability for oil yield and its components. Euphytica. 2014;195(2):183-195.

31. Volotovich AA, Silkova TA, Fomchenko NS, et al. Combining ability and heterosis effects in sunflower of Byelorussian Origin. Helia. 2008;48:111-118.

32. Ortis LG, Nestares G, Frutos E, et al. Combining ability analysis of agronomic traits in sunflower (Helianthusannuus L.). Helia. 2005;28(43):125-134.

33. Romanus KG, Hussein S, Mashela WP. Combining ability analysis and association of yield and yield components among selected cowpea lines. Euphytica. 2008;162(2):205-210.

34. Milić D, Katić S, Karagić Đ, et al. Genetic control of agronomic traits in alfalfa (M sativa ssp. sativaL.). Euphytica. 2011;182(1):25-33.

35. Al Lawati AH, Pierce CA, Murray LW, et al. Combining ability and heterosis for forage yield among elite alfalfa core collection accessions with different fall dormancy responses. Crop Science. 2010;50(1):150158

36. Segovia-Lerma A, Murray LW, Townsend MS, et al. Population- based diallel analyses among nine historically recognized alfalfa germplasms. Theoretical and Applied Genetics. 2004;109(8):1568-1575.

37. Bhandari HS, Pierce CA, Murray LW, et al. Combining abilities and heterosis for forage yield among high-yielding accessions of the alfalfa core collection. Crop Science. 2007;47:665-673.

38. Shukla SK, Pandey MP. Combining ability and heterosis over environments for yield and yield components in two-line hybrids involving thermosensitive genic male sterile lines in rice (Oryza sativa L.). Plant Breeding. 2008;127(1):28-32.

39. Qu Z, Li L, Luo J, et al. QTL mapping of combining ability and heterosis of agronomic traits in rice backcross recombinant inbred lines and hybrid crosses. PLoS One. 2012;7(1):e28463.

40. Verma OP, Srivastava HK. Genetic component and combining ability analyses in relation to heterosis for yield and associated traits using three diverse rice-growing ecosystems. Field Crops Research. 2004;88:91102

41. Joshi SK, Sharma SN, Singhania DL, et al. Combining ability in the F and $\mathrm{F}_{2}$ generations of diallel cross in hexaploid wheat (Triticum aestivum L. em. Thell). Hereditas. 2004;141(2):115-121.

42. Yücel C, Baloch FS, Özkan H. Genetic analysis of some physical properties of bread wheat grain (Triticum aestivum L. em Thell). Turkish Journal of Agriculture and Forestry. 2009;33(6):525-535.

43. Ashok Kumar A, Reddy BVS, Ramaiah B, et al. Gene effects and heterosis for grain iron and zinc concentration in sorghum [Sorghum bicolor(L.) Moench]. Field Crops Research. 2013;146:86-95.

44. Kenga R, Alabi SO, Gupta SC. Combining ability studies in tropica sorghum (Sorghum bicolor (L.) Moench). Field Crops Research. 2004;88(2-3):251-260.

45. Umakanth AV, Patil JV, Rani Ch, et al. Combining ability and heterosis over environments for stalk and sugar related traits in sweet sorghum (Sorghum bicolor (L.) Moench.). Sugar Tech. 2012;114(3):237-246.

46. Goncharenko AA, Krakhmalev SV, Ermakov SA, et al. Diallel analysis of grain quality traits in inbred winter rye lines. Russian Agricultural Sciences. 2013;39(1):13-19.

47. Singh P, Cheema DS, Dhaliwal MS, et al. Heterosis and combining ability for earliness, plant growth, yield and fruit attributes in hot pepper (Capsicum annuum L.) involving genetic and cytoplasmic-genetic male sterile lines. Scientia Horticulturae. 2014;168:175-188.

48. Golkar P, Arzani A, Rezaei AM. Genetic Analysis of Oil Content and Fatty Acid Composition in Safflower (Carthamus tinctorius L.). Journal of the American Oil Chemists'Society. 2011;88(7):975-982.

49. Banerjee PP, Kole PC. Analysis of genetic architecture for some physiological characters in sesame (Sesamum indicum L.). Euphytica. 2009;168(1):11-22.

50. El-Gabry MAH, Solieman TIH, Abido AIA. Combining ability and heritability of some tomato (Solanum lycopersicum L.) cultivars. International Society for Horticultural Science. 2014;167:153-157.

51. Blank AF, Rosa YR, Carvalho Filho JL, et al. A diallel study of yield components and essential oil constituents in basil (Ocimum basilicum L.). Industrial Crops and Products. 2012;38(1):93-98.

52. Bhateria S, Sood SP, Pathania A. Genetic analysis of quantitative traits across environments in Linseed (Linum usitatisimum L.). Euphytica. 2006;150(1):185-194.

53. Shikano T, Nakadate M, Fujio Y. An experimental study on strain combinations in heterosis in salinity tolerance of the guppy Poecilia reticulate. Fisheries Science. 2000;66(4):625-632. 
54. Adebambo AO. Combining abilities among four breeds of chicken for feed efficiency variation: a preliminary assessment for chicken improvement in Nigeria. Tropical Animal Health and Production. 2011;43:1465-1466.

55. Wang B, Gu W, Gao H, et al. Longitudinal genetic analysis for growth traits in the complete diallel cross of rainbow trout (Oncorhynchus mykiss). Aquaculturre. 2014;430:173-178.

56. Franco MC, Cassini ST, Oliveira VR, et al. Combining ability for nodulation in common bean (Phaseolusvulgaris L.) genotypes from Andean and Middle American gene pools. Euphytica. 2001;118(3):265270 .

57. Tyagi AP, Lal P. Line $\times$ tester analysis in sugar cane (Saccharum officinarum). South Pacific Journal of Natural Science. 2005;23(1):30 36.

58. Hallauer AR, Miranda JB. Testers and combining ability, in Quantitative genetics in maize breeding. In: Hallauer AR, Miranda JB, editors. Iowa State University Press, Ames, USA, 1988. p. 267-298.

59. Wassimi NN, Isleib TG, Hosfield GL. Fixed effect genetic analysis of a diallel cross in dry beans (Phaseolus vulgaris L.). Theoretical and Applied Genetics. 1986;72(4):449-454.

60. Azad MAK, Shah-E-Alam M, Hamid MA, et al. Combining ability of pod yield and related traits of groundnut (Arachis hypogaea L.) under salinity stress. The Scientific World Journal. 2014;589586:1-7.

61. Fehr WR. Principles of cultivar development: development of hybrid cultivars. Macmillan Publishing Company, New York, USA 539; 1993.

62. Singh I, Paroda RS, Behl RK. Diallel analysis for combining ability over environments in wheat. Wheat Information Services. 1986;61/62:74-76.

63. Baker RJ. Issues in diallel analysis. Crop Science. 1978;18(4):533-536.

64. Machida L, Derera J, Tongoona $\mathrm{P}$, et al. Combining ability and reciprocal cross effects of elite quality protein maize inbred lines in subtropical environments. Crop Science. 2010;50(5):1708-1717.

65. Melchinger A, Schmit W, Geiger HH. Comparison of testcrosses from $\mathrm{F}_{2}$ and first backcross populations in maize. Crop Science. 1998;28(5):743749 .

66. Smith JSC, Hussain T, Jones ES, et al. Use of doubled haploids in maize breeding: implications for intellectual property protection and genetic diversity in hybrid crops. Molecular Breeding. 2008;22(1):51-59.

67. Geleta LF, Labuschagne MT. Combining ability and heritability for vitamin $\mathrm{C}$ and total soluble solids in pepper (Capsicum annuum L.) Journal of the Science of Food and Agriculture. 2006;86(9):1317-1320.

68. Davis RL. Report of Plant breeder. Annual Report of the Pueto Rico Agriculture Experimental Station. 1927. p. 14-15.

69. Jenkins MT, Brunaon AM. A method of testing inbred line of maize in cross bed combinations. J Ann Sci Agron. 1932;24:523-530.

70. Tysdal HM, Kiesselbach TA, Westover HL. Alfalfa breeding. Coll Agric Univ Nebraska Agric. Exp Sta Res Bull. 1942;124:1-46.

71. Griffing B. Concept of general and specific combining ability in relation to diallel crossing system. Australian Journal of Biological Sciences. 1956b;9(4):463-493.

72. Kempthorne O. An introduction of genetics statistics. John Wiley and Sons, New York, USA. 1957 p. 458-471.

73. Kempthorne D, Curnow RN. The partial diallel cross. Biometrics. 1961;17(2):229-240

74. Comstock RE, Robinson HF. The components of genetic variance in populations of biparental progenies and their uses in estimating the average degree of dominance. Biometrics. 1948;4(4):254-266.
75. Rawlings JO, Cockerham CC. Analysis of double cross hybrid populations. Biometrics. 1962;18:229-244.

76. Kagoda F, Derera J, Tongoona P, et al. Genetic analysis of resistance to nematodes in inbred maize (Zeamays L.) and maize hybrids. Euphytica. 2011;182:377-393.

77. Vieira RA, Scapim CA, Moterle LM, et al. The breeding possibilities and genetic parameters of maize resistance to foliar diseases. Euphytica. 2012;185(3):325-336.

78. Zhang Y, Kang MS. DIALLEL-SAS: a SAS program for Griffing's diallel analyses. Agronomy Journal. 1997;89(2):176-182.

79. Chowdhry MA, Rafiq M, Alam K. Genetic architecture of grain yield and certain other traits in bread wheat. Pakistan Journal of Agricultural Research. 1992;13(3):216-220.

80. Christie BR, Shattuck VI. The Diallel Cross: Design, Analysis, and Use for Plant Breeders. Plant Breeding Reviews. 1992;9:9-36.

81. Dabholkar RR. Elements of Biometrical Genetics, Ashok Kumar Mittal Concept Publishing Company, New Delhi, India. 1992.

82. Singh RK, Chaudhary BD. Biometrical methods in quantitative genetic analysis, Kalyani Publishers, New Delhi, India. 1985.

83. Fisher RA. The arrangement of field experiments. Journal of Ministry of Agriculture. 1926;33:503-513.

84. Yates F. Complex experiments. Supplement to the Journal of the Royal Statistical Society. 1935;2:181-223.

85. Rwiza IH, Mwala M, Diallo A. Combining ability for grain yield of imidazolinone-resistant maize inbred lines under striga (Striga hermonthica) infestation, in Innovations as key to the green revolution in Africa. Bationo A, Waswa B, Okeyo JM et al. editors. Springer, Netherlands; 2011. p. 693-700.

86. Matzinger DF. Comparison of three types of testers for the evaluation of inbred lines of corn. Agronomy Journal.1953;45:493-495.

87. Rawlings JO, Thompson DL. Performance level as criterion for the choice of maize testers. Crop Science. 1962;2:217-220.

88. Allison JCS, Curnow RW. On the choice of tester parent for the breeding of synthetic varieties of maize (Zea mays L.). Crop Science. 1966;6(6):541-544.

89. Smith OS. Covariance between line per se and testcross performance. Crop Science. 1986;26(3):540-543.

90. Castellanos JS, Hallauer AR, Córdova HS. Relative performance of testers to identify elite lines of corn (Zea mays L.). Maydica. 1998;43:217-226.

91. Russell WAA. Comparison of five types of testers in evaluating the relationship of stalk rot in corn inbreed lines and stalk strength of the lines in hybrids combinations. Crop Science. 1961;1:393-397.

92. Akinwale RO, Badu-Apraku B, Fakorede MAB, et al. Heterotic grouping of tropical early-maturing maize inbred lines based on combining ability in Striga-infested and Striga-free environments and the use of SSR markers for genotyping. Field Crops Research. 2014;156:48-62.

93. Alumira J, Rusike J. The Green Revolution in Zimbabwe. Electronic Journal of Agricultural and Development Economics. 2005;2:50-66.

94. Mickleson HR, Cordova H, Pixley KV, et al. Heterotic Relationships among nine temperate and subtropical maize populations. Crop Science. 2001;41(4):1012-1020.

95. Gevers HO, Whythe IV. Patterns of heterosis in South African maize breeding material, in Proceedings of the 7th South African Maize Breeding Symposium, Potchefstroom. 1986. p. 21-26.

96. Olver RC. Maize breeding in Zimbabwe, in Proceedings of Eleventh 
South African Maize Breeding Symposium. 1988. p. 22-27.

97. CIMMYT. Maize inbred lines released by CIMMYT. A Compilation of 454 CIMMYT Maize Lines (CMLs), CML1-CML454, August 2001, Second Draft, CIMMYT, Mexico; 2001.

98. Comstock RE, Robinson HF. Estimation of the average dominance of genes, in Heterosis, Ames, Iowa, Iowa State College Press; 1952. p. 494-516.

99. Hill L, Becker HC, Tigerstedt PMA. Quantitative and ecological aspects of plant breeding,Chapman and Hall. UK; 1998. p. 67-83.

100. Hallauer AR. History contribution and future of quantitative genetics in plant breeding: Lessons from maize. Crop Science. 2007; 47:4-19.

101. Derera J, Pixley KV, Giga DP, et al. Resistance of maize to the maize weevil: III. Grain weight loss assessment and implications for breeding. Journal of Stored Products Research. 2014;59:24-35.

102. Derera J, Giga DP, Pixley VK. Resistance of maize to the maize weevil: II, Nonpreference. African Crop Science Journal. 2001;9(2):441-450.

103. Derera J, Tongoona P, Vivek BS, et al. Gene action controlling grain yield and secondary traits in southern African maize hybrids under drought and non-drought environments. Euphytica. 2008;162(3):411-422.

104. Singh RK, Chaudhary BD. Biometrical methods in quantitative genetic analysis, Kalyani Publishers, New Delhi, India. 1979.

105. Miranda Filho JB. Breeding methodologies for tropical maize, in Breeding strategies for maize production improvement in the tropics. Brandolini A, Salamini F, editors. Beramo, Italy; 1985. p. 341-365.

106. http://www4.ncsu.edu/ fisik/Analysis \%20 of\%20Diallel\%20 Progeny $\% 20$ Test $\% 20$ with $\% 20$ SAS.pdf.

107. Sharma JR. Statistical and biometrical techniques in plant breeding. Mohan lal Printers, Delhi; 2006. p. 265-285.

108. Acquaah G. Genetic analysis in plant breeding, in Principles of Plant Genetics and Breeding 108-162, Blackwell Publishing, Oxford, UK; 2007.

109. Hallauer AR, Carena MJ, Miranda Filho J. Quantitative genetics in maize breeding. Springer, Berlin; 2010.

110. Levings CS, Dudley JW. Evaluation of certain mating designs for estimation of genetic variance in autotetraploid alfalfa. Crop Science. $1963 ; 3: 532-535$

111. Fasahat P, Abdullah A, Muhammad K, et al. Expression of a key gene involved in the biosynthetic pathway of vitamin $\mathrm{E}$ in red pericarp and white rice grains. International Food Research Journal. 2013;20(6):3395-3401.

112. Fasahat P, Abdullah A, Muhammad K, et al. Red pericarp advanced breeding lines derived from Oryza rufipogon $\times$ Oryza sativa: Physicochemical properties, total antioxidant activity, phenolic compounds and vitamin E content. Advance Journal of Food Science and Technology. 2012;4(3):155-165.

113. Yallou CG, Menkir A, Adetimirin VO, et al. Combining ability of maize inbred lines containing genes from Zea diploperennis for resistance to Striga hermonthica (Del.) Benth. Plant Breeding. 2009;128(2):143-148.

114. Sibiya J, Tongoona P, Derera J. Combining ability and GGE biplot analyses for resistance to northern leaf blight in tropical and subtropical elite maize inbred lines. Euphytica. 2013;191(2):245-257.

115. Mukankusi C, Derera J, Melis R, et al. Genetic analysis of resistance to Fusarium root rot in common bean. Euphytica. 2011;182:11-23.

116. Thompson JP, Zwart RS, Butler D. Inheritance of resistance to root-lesion nematodes (Pratylenchus thornei and P. neglectus) in five doubledhaploid populations of wheat. Euphytica. 2012;188(2):209-219.
117. Bookmyer JM, Bonos SA, Meyer WA. Inheritance characteristics of brown patch resistance in tall fescue. Crop Science. 2009; 49(6):23022308.

118. Gao W, Baars JJP, Dolstra O, et al. Genetic variation and combining ability analysis of bruising sensitivity in Agaricus bisporus. PLoS One. 2013;8(10):e76826.

119. http://www.usm.edu.ph/onlinejournal/index.php /USMJournal/ article/ view/94.

120. Fan XM, Zhang Y, Liu L, et al. Improving Grain Yield and Yield Components of Temperate Maize Using Tropical Germplasm. Journal of New Seeds. 2010;11(1):28-39.

121. Fato P, Derera J, Tongoona P, et al. Heterotic orientation of tropical maize inbred lines towards populations ZM523 and Suwan-1 under downy mildew infestation. Euphytica. 2012;187(3):381-392.

122. Kanyamasoro MG, Karungi J, Asea G, et al. Determination of the heterotic groups of maize inbred lines and the inheritance of their resistance to the maize weevil. African Crop Science Journal. 2012;20(1):99-104.

123. Dhliwayo T, Pixley KV, Kazembe V. Combining ability for resistance to maize weevil among 14 Southern African maize inbred lines. Crop Science. 2005;45(2):662-667.

124. Mukanga M, Deedat Y, Mwangala FS. Toxic effects of five plant extracts against the larger grain borer, prostephanus truncates. African Journal of Agricultural Research. 2010;5(24):3369-3378.

125. Nkalubo ST, Melis R, Derera J, et al. Genetic analysis of anthracnose resistance in common bean breeding source germplasm. Euphytica. 2009;167(3):303-312.

126. Sokol MJA, Baker RJ. Evaluation of the assumptions required for the genetic interpretation of diallel experiments in self-pollinating crops. Canadian Journal of Plant Science. 1977;57(4):1185-1191.

127. Li ZK, Luo LJ, Mei HW, et al. Overdominant epistatic loci are the primary genetic basis of inbreeding depression and heterosis in rice. I. Biomass and grain yield. Genetics. 2001;158(4):1737-1753.

128. Luo LJ, Li ZK, Mei HW, et al. Overdominant epistatic loci are the primary genetic basis of inbreeding depression and heterosis in rice. II. Grain yield components. Genetics. 2001;158(4):1755-1771.

129. Mei HW, Li ZK, Shu QY, et al. Gene actions of QTLs affecting several agronomic traits resolved in a recombinant inbred rice population and two backcross populations. Theoretical and Applied Genetics. 2005;110(4):649-659.

130. Hua JP, Xing YZ, Xu CG, et al. Genetic dissection of an elite rice hybrid revealed that heterozygotes are not always advantageous for performance. Genetics. 2002;162(4):1885-1895.

131. Hua JP, Xing YZ, Wu WR, et al. Single-locus heterotic effects and dominance-by-dominance interactions can adequately explain the genetic basis of heterosis in an elite rice hybrid. Proceedings of the National Academy of Sciences. 2003;100(5):2574-2579.

132. Mei HW, Li ZK, Shu QY, et al. Gene actions of QTLs affecting several agronomic traits resolved in a recombinant inbred rice population and two backcross populations. Theoretical and Applied Genetics 2005;110(4):649-659.

133. Hallauer AR. Methods used in developing maize inbreds. Maydica. 1990;35(1):1-16.

134. Frascaroli E, Canè MA, Pè ME, et al. QTL detection in maize testcross progenies as affected by related and unrelated testers. Theoretical and Applied Genetics. 2009;118(5):993-1004.

135. Qi H, Huang J, Zheng Q, et al. Identification of combining ability loci for five yield related traits in maize using a set of testcrosses with 
introgression lines. Theoretical and Applied Genetics. 2013;126(2):369377.

136. He XH, Hu ZL, Zhang YM. Genome-wide mapping of QTL associated with heterosis in the RIL-based NCIII design. Chinese Science Bulletin. 2012;57(21):2655-2665

137. Lande R, Thompson R. Efficiency of marker-assisted selection in the improvement of quantitative traits. Genetics. 1990;124(3):743-756.

138. Austin DF, Lee M, Veldboom LR. Genetic mapping in maize with hybrid progeny across testers and generations: plant height and flowering. Theoretical and Applied Genetics. 2001;102(1):163-176.

139. Austin DF, Lee M, Veldboom LR, et al. Genetic mapping in maize with hybrid progeny across testers and generations: grain yield and grain moisture. Crop Science. 2000;40(1):30-39.

140. Liu XC, Chen SG, Chen JS, et al. Improvement of combining ability for restorer lines with the identified SSR markers in hybrid rice breeding. Breeding Science. 2004;54(4):341-346.

141. Belicuas PR, Aguiar AM, Bento DAV, et al. Inheritance of the stay-green trait in tropical maize. Euphytica. 2014;198(2):163-173.

142. Huang J, Qi H, Feng X, et al. General combining ability of most yieldrelated traits had a genetic basis different from their corresponding traits per se in a set of maize introgression lines. Genetica. 2013;141(10 12):453-461.
143. Li L, Kaiyang L, Zhaoming C, et al. Gene actions at loci underlying several quantitative traits in two elite rice hybrids. Molecular Genetics and Genomics. 2010;284(5):383-397.

144. He XH, Xu CW, Kuai JM, et al. Principal factors affecting the power of detection and accuracy of QTL mapping. Acta Agronomica Sinica. 2001;27:469-475.

145. Su CF, Zhao TJ, Ga JY. Simulation comparisons of effectiveness among QTL mapping procedures of different statistical genetic models. Acto Agronomica Sinica. 2010;36:1100-1107.

146. Stuber CW. Success in the use of molecular markers for yield enhancement in corn, In Proceedings of 49th Annual Corn and Sorghum Industry Research Conference 232-238, ASTA, Washington D.C., USA;1994.

147.Zehr BE, Dudley JW, Chojecki J, et al. Use of RFLP markers to search for alleles in a maize population for improvement of an elite hybrid. Theoretical and Applied Genetics. 1992;83:813-820. 